\title{
The Voting Rights Act in Winter: The Death of a Superstatute
}

\author{
Luis Fuentes-Rohwer \\ Indiana University Maurer School of Law, Ifr@indiana.edu \\ Guy-Uriel Charles \\ Duke Law School, charles@law.duke.edu
}

Follow this and additional works at: https://www.repository.law.indiana.edu/facpub

Part of the Civil Rights and Discrimination Commons, Election Law Commons, and the Legislation Commons

\section{Recommended Citation}

Fuentes-Rohwer, Luis and Charles, Guy-Uriel, "The Voting Rights Act in Winter: The Death of a Superstatute" (2015). Articles by Maurer Faculty. 2048.

https://www.repository.law.indiana.edu/facpub/2048

This Article is brought to you for free and open access by the Faculty Scholarship at Digital Repository @ Maurer Law. It has been accepted for inclusion in Articles by Maurer Faculty by an authorized administrator of Digital Repository@Maurer Law. For more information, please contactrvaughan@indiana.edu.

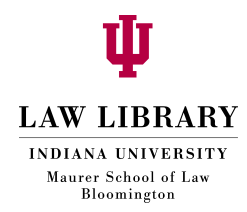




\title{
The Voting Rights Act in Winter: The Death of a Superstatute
}

\author{
Guy-Uriel E. Charles* E E Luis Fuentes-Rohwer**
}

\begin{abstract}
The Voting Rights Act ("VRA"), the most successful civil rights statute in American history, is dying. In the recent Shelby County decision, the U.S. Supreme Court signaled that the anti-discrimination model, long understood as the basis for the VRA as originally enacted, is no longer the best way to understand today's voting rights questions. As a result, voting rights activists need to face up to the fact that voting rights law and policy are at a critical moment of transition. It is likely the case that the superstatute we once knew as the VRA is no more and is never to return. If so, we need to figure out what, if anything, can, will, or should replace it. But before figuring out where to go from here, we need to understand first how we arrived at the moment of the VRA's disintegration so as not to repeat the mistakes of the not too distant past. In this Article, we argue that the VRA is dying because the consensus over the existence and persistence of racial discrimination in voting has dissolved. From this premise, we outline three paths for the future of voting rights policy: $(I)$ rebuilding a new consensus over the racial discrimination model; (2) forging a new consensus over what we call an autonomy model; or (3) reconceiving voting rights in universal terms.
\end{abstract}

* Charles S. Rhyne Professor of Law, Duke Law School.

** Professor of Law and Harry T. Ice Fellow, Indiana University Maurer School of Law.

Many readers kindly offered much advice and criticism, and we are immensely grateful: Joseph Blocher, James Boyle, Josh Chafetz, Mike Dorf, Chris Elmendorf, Rick Garnett, Heather Gerken, Rick Hasen, Michael Kang, Rick Pildes, Bill Popkin, Aziz Rana, Stephen Sachs, David Schleicher, Peter Strauss, Gerald Torres, and Deborah Widiss. Special thanks to Bill Eskridge, John Ferejohn, Abbe Gluck, and Maggie Lemos who provided extensive feedback. We have presented this Article in one form or another to the law faculties at Cornell, Duke, Emory, Florida State, Georgetown, Indiana University Maurer, Minnesota, Notre Dame, St. Louis, UC Davis, Virginia, and Washington University. We are extremely grateful for the many comments and criticisms we have received throughout. 


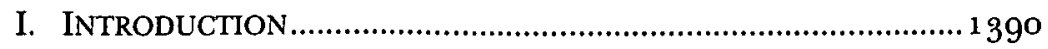

II. The Voting RIGHTS ACT AS A SUPERSTATUTE ........................ 1394

A. LANDMARK STATUTE................................................... 1396

B. COOPERATION................................................................ 1403

1. Cooperation as Deference to Congress ......................1404

2. Cooperation as Deference to the Executive Branch........................................................... 1407

III. PRAGMATIC INTERPRETATION .......................................... 1410

A. NORTHWEST AUSTIN AS A CHAIN LETTER .........................1410

B. THE BEGINNING: ALLEN ..................................................1415

1. The Act and Private Attorneys General .....................1415

2. Private Attorneys General and Local Federal

Courts................................................................1416

3. Local Three-Judge Courts .....................................1418

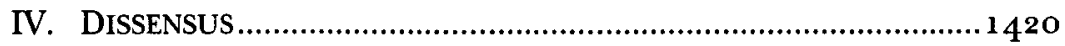

A. THE END OF THE RACIAL DISCRIMINATION CONSENSUS............1420

B. THREE CONCEPTIONS OF DISSENSUS ...................................1423

1. What Is Racial Discrimination? .................................1423

2. Does Geographical Targeting Remain Sensible?......1424

3. Race v. Partisanship Redux.................................... 1426

V. Forging A New Consensus: THREE MOdELS..........................1430

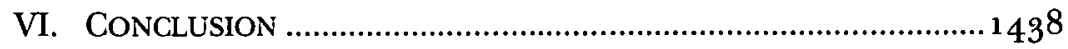

\section{INTRODUCTION}

The Voting Rights Act ("VRA") is dying. As we begin to chart a new course, we must understand why. The unraveling of the VRA is a remarkable moment in the history of voting rights law in the United States. Not only is the Act widely regarded as the most successful civil rights statute ever enacted by Congress, but it is also unlike ordinary legislation. From the moment the Supreme Court first addressed the constitutionality of the Act in South Carolina ข. Katzenbach, ${ }^{1}$ the Court has generally treated the VRA like a special statute, a superstatute." A term of art, the word "superstatute" describes a category of landmark legislation that addresses a significant public policy problem that if left unresolved would call into question a fundamental

1. See generally South Carolina v. Katzenbach, 383 U.S. 301 (1966).

2. See infra Part II. 
constitutional commitment.s The Supreme Court has, until recently, by and large, accepted the voting rights agenda represented by the VRA and viewed Congress and the executive branch as co-equal partners that were effectuating constitutional commands.

One cannot read the early voting rights cases and view the Court as a neutral and detached arbiter on voting rights policy. As befits a superstatute, the Court interpreted the VRA pragmatically and gave effect to Congress's aim in enacting the statute even if it meant interpreting both the statute and the Constitution elastically in order to do so. More importantly, the Court has generally viewed Congress and the Executive as its partners when interpreting the VRA. Consequently, the VRA, as it existed prior to the Court's recent decision in Shelby County $v$. Holder, 4 was best understood as a joint product of Congress, the Executive, and the Court.

Shelby County marks the death of the VRA as a superstatute. Specifically, the Court struck down the Act's coverage formula, which identified the states that were subject to the Act's special provisions, and it effectively neutered the existing preclearance regime.5 This is significant; it signals that the partnership between Congress and the Executive, on one side, and the Court, on the other side, has disintegrated. With Shelby County and its herald, Northwest Austin Municipal Utility District No. One v. Holder ("Northwest Austin"), ${ }^{6}$ the Court is cautiously dismantling the most important civil rights statute in our nation's history. The strong message of Shelby County is that the voting rights era-and maybe much more broadly, the civil rights era-as we have known it, is over.

The question for the foreseeable future is where does voting rights policy go from here? Not surprisingly, voting rights activists have called on President Barack Obama and Congress to enact a new coverage formula. 7 Indeed, a few weeks after the Shelby County decision, President Obama convened civil rights leaders to the White House to reassure them that his Administration is

3. See infra notes $15^{-20}$ and accompanying text.

4. Shelby Cnty. v. Holder, 133 S. Ct. 2612,2631 (2013) (invalidating the VRA's section 4 (b) preclearance formula).

5. Id.

6. Nw. Austin Mun. Util. Dist. No. One v. Holder, 557 U.S. 193 (2009).

7. Commentators have suggested various fixes to the VRA, including using section 2 lawsuits as the basis for designing a new coverage formula. See Bernard Grofman, Devising a Sensible Trigger for Section 5 of the Voting Rights Act, 12 ELECTION L.J. 332, 334 (2013) (proposing that social science data on section 2 litigation be used to create a new trigger for section 5 coverage); see also Christopher S. Elmendorf \& Douglas M. Spencer, The Geography of Racial Stereotyping: Evidence and Implications for VRA Preclearance After Shelby County, 102 CALIF. L. REV. 1123, 1174 (2014) (arguing that Congress should create a default coverage formula that could then be updated by the Department of Justice or another agency); Spencer Overton, Voting Rights Disclosure, 127 HARV. L. REV. F. 19, 29 (2013) (arguing that Congress should, among other things, update the preclearance formula). 
committed to a bipartisan fix for the Act. ${ }^{8}$ Attorney General Eric Holder, for his part, promised to use the remaining sections of the VRA to vigorously enforce voting rights policy. And as evidence of his commitment, Attorney General Holder filed suit in Texas and asked a lower court to use section 3(c) of the VRA to once again require the state to preclear some voting changes. 9

As these early responses to Shelby County reveal, many of the proposed fixes and reactions to the decision reflect an attempt to restore the status quo ante. These early efforts have been aimed at promoting aggressive section 2 litigation, using section 3 's bail-in provision, and using section 2 cases to craft a new coverage provision. Importantly, these strategies critically depend upon the continued persistence of racial discrimination in voting by state actors as the central problem of voting rights policy. This is because the most critical justification for the VRA has long been the presence, profundity, and persistence of intentional racial discrimination in voting by state actors. ${ }^{10}$ More importantly, modern voting rights law and policy is held together by a consensus that clearly understood the reality, pervasiveness, and extent of racial discrimination by state actors in democratic politics." This antidiscrimination consensus is the foundation upon which modern voting rights law is built.

However, rightly or wrongly, the Court no longer believes that intentional racial discrimination by state actors remains the dominant problem of democratic politics. The decision in Shelby County is clear evidence that the Court's current conservative majority believes that the regulatory model that has undergirded modern voting rights policy and has been in place for almost 50 years is no longer tenable because of what it views as the sufficient decline of intentional racial discrimination by state actors. ${ }^{12}$ Shelby

8. See Jackie Calmes, Obama Reassures Leaders on Enforcing Voting Rights, N.Y. TimEs (July 29, 2013), http://www.nytimes.com/2013/o7/30/us/politics/obama-reassures-leaders-on-enforcingvoting-rights.html.

9. See Adam Liptak \& Charlie Savage, U.S. Asks Court to Limit Texas on Ballot Rules, N.Y. TIMES (July 25, 2013), http://www.nytimes.com/2013/o7/26/us/holder-wants-texas-to-clearvoting-changes-with-the-us.html.

10. S. REP. NO. $109-295$, at 2 (2006) ("The Voting Rights Act of 1965 was enacted to remedy 95 years of pervasive racial discrimination in voting, which resulted in the almost complete disenfranchisement of minorities in certain areas of the country." (citation omitted)).

11. See, e.g., $15^{2}$ CONG. REC. $\mathrm{H}_{5} \mathrm{O}_{55}$ (daily ed. July 1 2, 2006) (statement of Rep. Gonzalez) ("What a wonderful opportunity for Democrats and Republicans to come together and reignite that shining light in the conscience of man."); id. at $\mathrm{H}_{5}{ }_{53}$ (statement of Rep. Scott) ("In Virginia, my home State, because of all sorts of schemes and barriers, there were no African American State legislators or Federal legislators, not a single African American State or Federal judge in $1964 \ldots$. We do not need to return to the days before $196_{5} . "$ ).

12. As Professor Samuel Issacharoff wrote recently in advancing a similar point: "The critical assumptions of the challenged provisions of the Act corresponded to a world in which overt racial exclusion meant that black citizens faced first-order impediments simply to getting registered to vote and in which only the federal government could assume the responsibility to challenge the persistence of Jim Crow." Samuel Issacharoff, Comment, Beyond the Discrimination Model on Voting, 127 HARV. L. REV. 95, 96-97 (2013). 
County is the product of the majority's frustration with what it regards as the backward-looking nature of the VRA's statutory scheme. In other words, the discrimination consensus is disintegrating. And, as we argue below, Shelby County signals the unraveling of the voting rights law and policy of the past half-century.

The existing dissensus about the nature and extent of racial discrimination, coupled with the Court's skepticism about what it views as a backward-looking statutory framework, surrounds the future of voting rights policy in a fog of uncertainty. Nevertheless, one thing is clear: any attempt to use the existing statutory provisions to recreate the status quo ante, which turns upon the persistence of intentional discrimination as a critical fulcrum, is likely to ground upon the same shoals that grounded sections 4 (b) and 5 .

Moreover, to the extent that intentional racial discrimination by state actors is not sufficiently descriptive of the present risk to voting rights and not sufficiently predictive of the future of voting rights, voting rights policy built upon the disintegrating consensus of intentional discrimination is not only backward-looking, but also bad policy. The attempt to preserve as much of the old model as possible is likely to put pressure on the existing provisions of the Act, in particular sections 2 and 3 (c), to capture as much of what has been lost as possible. ${ }^{13}$ Creative interpretations of sections 2 and $3(\mathrm{c})$ will simply increase the risk that the current Court majority further dismantles-and hastens the demise of-the remaining provisions of the Act. This is the reason why we are skeptical that the proposed fixes to Shelby County under discussion and the attempt to restore the status quo ante will have long-term traction.

Voting rights activists need to face up to the fact that voting rights law and policy are at a critical moment of transition. It is likely the case that the superstatute we once knew as the VRA is no more and is never to return. If so, we need to figure out what, if anything, can, will, or should replace it. But before figuring out where to go from here, we need to first understand how we arrived at the moment of the VRA's disintegration so as not to repeat the mistakes of the near past.

This Article proceeds in four parts. Part II examines how the Court understood the VRA prior to Shelby County and focuses on how the Court cooperated with both Congress and the Department of Justice ("DOJ") to give effect to the Act. Part III focuses specifically on how the Court has interpreted the VRA. In particular, we argue that the Court has generally interpreted the Act pragmatically. Part IV explores the current dissensus over voting rights policy, which we argue is a function of the Court's perception that intentional discrimination is no longer the critical problem in voting rights policy and a

13. For arguments that section $3(c)$ can be an effective tool in voting right enforcement, see generally Travis Crum, Note, The Voting Rights Act's Secret Weapon: Pocket Trigger Litigation and Dynamic Preclearance, 19 YALE L.J. 1992 (2010); Roseann R. Romano, Note, Devising a Standard for Section 3: PostShelby County Voting Rights Litigation, 100 IOWA L. REV. 387 (2014). 
function of the failure of Congress to provide a new focus for voting rights law other than the intentional discrimination model. Part V looks to the future and the questions that a new consensus in voting rights policy must face.

\section{The Voting RIGHTS ACT AS A SUPERSTATUTE}

To understand the extent to which the Court's decision in Shelby County is a radical departure from prior voting rights precedent and why it marks an important moment in voting rights history, we must first understand the way that the Court has viewed the VRA in the past. As we show in this Part, the Supreme Court never regarded the VRA as just another ordinary statute. Generally, the Court has understood the VRA as representing a significant historical intervention in the life of the country. As such, the Court has willingly partnered with Congress and the executive branch to give effect to the Act. Though Congress and the DOJ certainly deserve much credit for the fact that the VRA has been such a successful statute, the Court deserves a significant amount of credit as well. ${ }^{24}$ More importantly, the Court has rarely viewed itself as a neutral arbiter of voting rights policy. Rather, the Court has interpreted the VRA pragmatically, often expansively, and in a manner consistent with what it views as the Act's ideals.

To appreciate this argument, we situate the VRA within a body of scholarship and framework that identifies a set of statues, including the VRA, as "superstatutes." 15 A superstatute is landmark legislation that addresses a significant public policy question, the resolution of which compels the cooperation of all branches of government. ${ }^{16}$ Because superstatutes depend upon a fair amount of inter-branch cooperation, the courts and administrative agencies are also involved in a significant amount of policymaking.

A superstatute takes form when a fundamental element of our constitutional or first-order principles is renegotiated. A superstatute is the instantiation of that renegotiation. Superstatutes occupy the interstices between constitutional commitments and ordinary legislation. While superstatutes do not quite have the normative pull of constitutional provisions, they are much more than ordinary legislation. Superstatutes are aimed at the big, fundamental questions of the day. Though these fundamental public policy questions may not always rise to the level of constitutional or first-order principle, they are clearly beyond the ken of everyday legislation.

14. Richard Valelly also makes this point in his wonderful book. See RICHARD M. VALELLY, THE TWo RECONSTRUCTIONS: THE STRUGGLE FOR BLACK ENFRANCHISEMENT 202-03 (2004).

15. See William N. ESKridge, JR. \& JOHN FEREjohn, A Republic of Statutes: The New AMERICAN CONSTITUTION 88 (2010).

16. William N. Eskridge, Jr. \& John Ferejohn, SuperStatutes, 50 DUKE L.J. 1215,1216 (2001); see also Stephen M. Rich, One Law of Race?, 100 IOWA L. REV. 201, 207 n.20 (2014) (discussing the role of superstatutes in shaping "legal policy and popular opinion"). 
Two criteria distinguish ordinary legislation from superstatutes. These criteria may not be sufficient, but they are necessary. First, a superstatute must be a landmark statute. By landmark statute we mean a major piece of legislation that either establishes an important principle or addresses a significant public policy problem that, if left unresolved, would call into question a fundamental (constitutional or first-order) commitment. ${ }^{17}$ This is not to say that the principle or commitment is not contestable or that broad consensus exists. Moreover, the commitment need not be one of constitutional import. ${ }^{18}$ But the statute must address a significant national problem or stand for a fundamental principle. ${ }^{19}$

Second, a superstatute demands more than typical interbranch engagement or interaction. A necessary distinguishing characteristic of a superstatute is that the statute obliges a significantly greater level of engagement by the judicial and executive branches than would be expected if one were applying the traditional principal-agent model of statutory interpretation..$^{\circ}$ What makes a statute eligible for super status is that the

17. The Civil Rights Act of 1964 is a good example of a superstatute that implicates both constitutional and first-order principles. See Civil Rights Act of 1964 , Pub. L. No. 88-352, 78 Stat. 241 (codified as amended in scattered sections of 42 U.S.C.).

18. The Sherman Antitrust Act is a good example of a superstatute that may not implicate an explicit constitutional principle. See Sherman Antitrust Act, ch. 647, 26 Stat. 209 (189o) (codified as amended at 15 U.S.C. $\$ \S 1-7$ (2012)); see also Bus. Elecs. Corp. v. Sharp Elecs. Corp, ${ }_{4} 8_{5}$ U.S. 717,732 (1988) ("The Sherman Act adopted the term 'restraint of trade' along with its dynamic potential. It invokes the common law itself, and not merely the static content that the common law had assigned to the term in $1890 . ")$.

19. The recently enacted Patient Protection and Affordable Care Act serves as a good example here. See Patient Protection and Affordable Care Act, Pub. L. No. 11 1-1 48, 124 Stat. 119 (2010) (codified as amended in scattered sections of $4^{2}$ U.S.C.). It is a major piece of legislation that addresses a significant problem. It may also be understood as establishing or giving rise to an important principle-a right to affordable health care. See Abbe R. Gluck, Essay, Intrastatutory Federalism and Statutory Interpretation: State Implementation of Federal Law in Health Reform and Beyond, 121 YALE L.J. 534, 539 (2011) (discussing federalism in the context of "the first major piece of

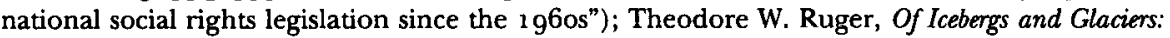
The Submerged Constitution of American Healthcare, 75 L. \& CONTEMP. ProBS. 215,233 (2012) (arguing that the legislation establishes the principle of affordable health care through "cooperative federalism").

20. On this model, statutory interpreters are agents assigned with the task of translating and implementing the wishes of the legislature, its principal. See, e.g., Richard A. Posner, Legal Formalism, Legal Realism, and the Interpretation of Statutes and the Constitution, 37 CASE W. RES. L. REV. 179,189 (1986) ("In our system of government the framers of statutes . . . are the superiors of the judges. The framers communicate orders to the judges through legislative texts. ... If the orders are clear, the judges must obey them."); Cass R. Sunstein, Interpreting Statutes in the Regulatory State, 103 HARV. L. REV. 405, 415 (1989) ("According to the most prominent conception of the role of courts in statutory construction, judges are agents or servants of the legislature... . The judicial task is to discern and apply a judgment made by others, most notably the legislature." (footnote omitted)); Nicholas S. Zeppos, Legislative History and the Interpretation of Statutes: Toward a Fact-Finding Model of Statutory Interpretation, 76 VA. L. REV. 1295,1313 (199o) ("Traditional democratic theory suggests that the court interpreting a statute must act as the faithful agent of the legislature's intent."). 
coordinate branches are compelled to self-consciously lend their institutional capital and institutional competence in order to resolve the public policy question the statute addresses. More importantly, the coordinate branches take ownership of the statute or its public policy domain. As we argue below, this necessarily means that statutory interpreters will engage in superstatutory interpretation-and superstatutory interpretation will be justified-when the institutional expertise of the coordinate branches is required to effectuate the statute's broad and evolving purpose. While courts in some cases will have a significant advantage over Congress and administrative agencies, other times, in order to effectuate the statute's purpose, these agencies must take the lead in broadly interpreting the statute and filling significant statutory gaps. Thus, depending upon the circumstances, courts will have to defer to agencies or Congress and vice versa. As a general rule, no one institution will be supreme over another. Deference is contextual. This is precisely what we see with the VRA.

\section{A. LANDMARK STATUTE}

As a threshold matter, superstatutes differ from ordinary statutes in that superstatutes are landmark statutes directed toward resolving fundamental public policy problems. In our view, statutes can reach landmark status in one of two ways.

First, a statute that is enacted explicitly to elucidate or give effect to a constitutional command is likely to be a landmark statute. This is true, for example, in the case of the VRA. On its terms, the aim of the VRA is to eliminate racial discrimination in the electoral process. ${ }^{21}$ Eliminating racial discrimination is obviously a core or fundamental commitment, constitutionalized in the Fifteenth Amendment.2?

A statute may also satisfy this condition when it gives effect to democratic principles that are fundamental and deeply rooted in our legal tradition. The Sherman Antitrust Act is an example. Through the Act, Congress has codified the fundamental democratic principle of free competition and the notion that monopolistic behavior is a threat to economic liberty. ${ }^{23}$ Other statutes

21. See South Carolina v. Katzenbach, $3^{8} 3$ U.S. 301,308 (1966) (explaining that the VRA was intended "to banish the blight of racial discrimination in voting, which has infected the electoral process in parts of our country for nearly a century").

22. For another example of a statute that aims to promote a core democratic commitment, see Administrative Procedure Act (APA), Pub. L. No. 79-404, 6o Stat. 237 (1946) (codified as amended at 5 U.S.C. $\$ \$ 55^{1-559}$ (2012)). The APA, in the words of Senator Pat McCarran, "is a bill of rights for the hundreds of thousands of Americans whose affairs are controlled or regulated in one way or another by agencies of the Federal Government. It is designed to provide guaranties of due process in administrative procedure." 92 CONG. REC. 2149 (1946) (statement of Sen. McCarran). In other words, the APA reflects the core democratic commitments expressed in the due process clauses of both the Fifth and Fourteenth Amendments.

23. See Louis Brandeis, Monopoly, in THE WORDS OF JUSTICE BRANDEIS 131, 133 (Solomon Goldman ed., 1953) ("Concentration of power has been shown to be dangerous in a democracy, 
that must be considered landmark statutes include the Social Security Act, ${ }^{24}$ the National Labor Relations Act, ${ }^{25}$ and the Civil Rights Act of $1964{ }^{26}$ Consider also the longstanding health-care debate, which culminated in the enactment of the Affordable Care Act. As Ted Ruger observes, we are "in the midst of a fractious and polyphonic debate about the future shape of [the United States'] healthcare finance and delivery system. ${ }^{27}$ This is a debate, Ruger argues, that "implicates foundational questions of government authority and constitutional limitation that have transcended the traditional boundaries of health law." 28 The common thread running through these statutes is the fact that they give expression to basic, core American ideals, what Cass Sunstein calls "constitutive commitments."29

Second, a landmark statute is likely to be a statute that generates a new paradigm or baseline. One may define "paradigm" as "the entire constellation of beliefs, values, techniques, and so on shared by the members of a given community." $3^{\circ}$ It is this constellation, in turn, that forms the basis for further study and reflection. For our purposes, by paradigm we mean that the statute must generate a new line of thinking that is different from the one in place prior to the promulgation of the statute. The critical focus here is not that the statute necessarily embodies the new paradigm itself, but that it gives rise to

even though that power may be used beneficently."); Elizabeth Fox-Genovese, Women's Rights, Affirmative Action, and the Myth of Individualism, 54 GEO. WASH. L. REV. 338, 369 (1986) ("'Jacksonian Democracy' meant, among other things, government action to prevent monopoly and other impediments to individual access to the market. The Sherman Antitrust Act could be interpreted in the same spirit."); P. Blake Keating, Historical Origins of Workmen's Compensation Laws in the United States: Implementing the European Social Insurance Idea, 11 KAN. J.L. \& PUB. POL'Y 279, 295 (2001-2002) ("The unrest of the Progressives owed much to this class of citizens whose powers of economic decision had been limited by the rise of the corporation. They feared an end to traditional American democracy, for the great combinations were such concentrated centers of wealth and power that they could subvert all other interests."); Tamara R. Piety, Against Freedom of Commercial Expression, 29 CARDOzo L. REV. 2583, 2671 (2008) ("The Framers noted the potential for large, for-profit, organizations to accumulate the type of power that can threaten the stability of democracy.").

24. Social Security Act, Pub. L. No. $74^{-2} 71,49$ Stat. 620 (1935) (codified as amended at 42 U.S.C. $\S \S 301-1397 \mathrm{~mm}(2012)$ ).

25. National Labor Relations Act, Pub. L. No. 74-198, 49 Stat. 449 (1935) (codified as

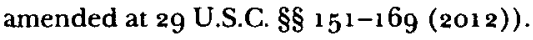

26. Civil Rights Act of 1964 , Pub. L. No. 88-352, 78 Stat. 241 (codified as amended in scattered sections of $4^{2}$ U.S.C.); see also Robert C. Post \& Reva B. Siegel, Essay, Equal Protection by Law: Federal Antidiscrimination Legislation After Morrison and Kimel, 110 YALE L.J. 441, 502 (2000) (arguing that "Americans now believe that a core function of the federal government is to prohibit discrimination in the public and private sectors").

27. Ruger, supra note 19 , at 215 .

28. Id.

29. CASS R. SUNSTEIN, THE SECOND BILL OF RIGHTS: FDR'S UNFINISHED REVOLUTION AND WHY WE NEED IT MORE THAN EVER 61-62 (2004) (stating that constitutive commitments "are not mentioned expressly," but "[t]hey have a special place in the sense that they are widely accepted and cannot be eliminated without a fundamental change in social understanding").

3o. Thomas S. Kuhn, The Structure OF Scientific Revolutions 174 (4th ed. 2012 ). 
the new paradigm..$^{1}$ Crucially, we note that paradigms are not merely replicated. Instead, they are subject to further elucidation and articulation, "like an accepted judicial decision in the common law." $"$ " The new paradigm may be in the service of addressing an important public policy, such as racial equality in the political process, or it may announce a new framework changing the balance and separation of powers, such as the Administrative Procedure Act.98

Consider this point in the context of the VRA. The statute is paradigmshifting because, by making democratic participation practically available to citizens of color, the VRA re-conceptualized American democracy. As a consequence of the VRA, people of color in all states became self-governing, a privilege that was previously reserved to whites. The VRA redefined "We the People" by exerting a gravitational pull on the meaning of the Constitution itself. The VRA gave life to the inert ideals of the Fifteenth Amendment.34 In order to realize the promises of the Fifteenth Amendment, the VRA changed the baseline that demarcated the relationship between federal and state governments, and between the Supreme Court and coordinate branches of the federal government. 35

Guinn v. United States set the pre-VRA baseline for our understanding of the meaning of the Fifteenth Amendment and the existing line that marks the relationship between the federal government and the states. Following its admission to the Union in 1907 , Oklahoma amended its state constitution in 1910 to impose a literacy requirement for voting. In Guinn, the Supreme Court addressed the constitutionality of Oklahoma's literacy test and of an attendant grandfather clause that ensured that the literacy test applied only to black male Oklahomans. $3^{6}$ The literacy test precluded anyone who could not "read and write any section of the Constitution of the state of Oklahoma" from registering to vote and from voting. ${ }^{37}$ The grandfather clause provision included the following exemption:

31. Thus, this criterion differs from one of Eskridge and Ferejohn's criterion for identifying a superstatute, which is that the statute "embodie[s] a new principle or policy displacing common law baselines, responsive to important social or economic challenges facing the country." ESKRIDGE \& FEREJOHN, supra note 15 , at 26.

32. KUHN, supra note 3o, at 23.

33. Administrative Procedure Act (APA), Pub. L. No. 79-404, 6o Stat. 237 (1946) (codified

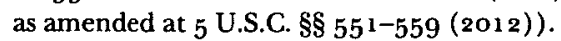

34. See J. MORGAN KOUSSER, COLORBLind INJUSTICE: MinORITY VOTING RiGHTS AND THE UNDOING OF THE SECOND RECONSTRUCTION 1 2-1 3 (1999).

35. For an illustration of the point that the VRA was paradigm-shifting, compare Guinn v. United States, $23^{8}$ U.S. $347,367-68$ (1915) (finding a grandfather clause exception to literacy tests unconstitutional), and Lassiter v. Northampton Cnty. Bd. of Elections, 360 U.S. $45,53-54$ (1959) (upholding the use of literacy tests on the basis that their application was not discriminatory), with Katzenbach v. Morgan, 384 U.S. $641,657-58$ (1966) (upholding the constitutionality of the VRA provision placing a temporary ban on literacy tests).

36. Guinn, $23^{8}$ U.S. at $35^{6-57}$.

37. Id. at 357 . 
[N]o person, who was, on January 1,1866 , or at any time prior thereto, entitled to vote under any form of government, or who at that time resided in some foreign nation, and no lineal descendant of such person, shall be denied the right to register and vote because of his inability to so read and write sections of such Constitution. $3^{8}$

Because black male Oklahomans were not guaranteed suffrage until the ratification of the Fifteenth Amendment in 1870 , the grandfather clause assured that the literacy test applied only to them. The plaintiffs in Guinn were state election officials prosecuted by the federal government for conspiring to deprive black voters of their right to vote in Oklahoma. 39

In a unanimous opinion, the Court easily concluded that the grandfather clause violated the Fifteenth Amendment. The Fifteenth Amendment, the Court observed, "in express terms restricts the power of the United States or the states to abridge or deny the right of a citizen of the United States to vote on account of race, color, or previous condition of servitude." 40 Moreover, the Fifteenth Amendment is "self-executing and reached without legislative action the conditions of discrimination against which it was aimed." ${ }^{1}$ The Court concluded that there is no "room for any serious dispute" that the grandfather clause violated the Fifteenth Amendment. $4^{2}$ Though the clause did not explicitly discriminate on the basis of race, the Court argued that the clause "inherently brings that result into existence since it is based purely upon a period of time before the enactment of the [Fifteenth] Amendment, and makes that period the controlling and dominant test of the right of suffrage." 43 The Court noted that there was no justification for picking 1866 as the grandfathering date except to avoid the application of the Fifteenth Amendment.44 By setting the grandfathering line before the ratification of the Fifteenth Amendment, the clause "re-creates and perpetuates the very conditions which the Amendment was intended to destroy." 45 Consequently, the grandfather clause was unconstitutional.

But the Court treated the literacy test very differently. As sure as the Court was that the grandfather clause violated the Fifteenth Amendment, it was equally sure that the literacy test did not. "No time need be spent on the question of the validity of the literacy test," Chief Justice White declared. $4^{6}$ The literacy test standing alone is "but the exercise by the state of a lawful

$$
\begin{array}{ll}
38 . & I d . \\
39 . & I d . \text { at } 354 . \\
4^{\circ} . & I d . \text { at } 3^{62 .} \\
41 . & I d . \text { at } 363 . \\
42 . & I d . \\
43 . & I d . \text { at } 3^{6}-65 . \\
44 . & I d . \text { at } 3^{6} . \\
45 . & I d . \text { at } 3^{60} . \\
4^{6 .} & I d . \text { at } 366 .
\end{array}
$$


power vested in it, not subject to [judicial] supervision, and indeed, its validity is admitted." 47 And indeed, its validity was admitted. $4^{8}$

The Court and the federal government agreed that the state had the power to promulgate a literacy test and that the test did not implicate the Fifteenth Amendment.49 The Fifteenth Amendment, the Court remarked, " $d$ [id] not change, modify, or deprive the states of their full power as to suffrage except, of course, as to the subject with which the Amendment deals and to the extent that obedience to its command is necessary." $5^{\circ}$

Indeed, the Court declined to rule the whole scheme unconstitutional and decided to excise the grandfather clause from the literacy requirement on the theory that the literacy requirement was "a right whose exercise lies at the very basis of government" and that a court should refrain from interfering with the state's prerogative unless absolutely necessary. ${ }^{51}$ Moreover, and most saliently, the United States conceded it did not have the constitutional authority to preclude the state from promulgating a literacy test. $5^{2}$

Guinn warranted at least three observations about the constitutional baseline. First, the Fifteenth Amendment prohibited the states from implementing grandfather clauses that facilitated racial discrimination in voting.53 Second, where the states violated the Fifteenth Amendment, the federal government did not overstep its boundaries in prosecuting state officials. Third, however, the Fifteenth Amendment did not authorize the federal government to prosecute state officials when the state sought to

47. Id.

48. Id. at 359. The Court noted:

No question is raised by the government concerning the validity of the literacy test provided for in the amendment under consideration as an independent standard since the conclusion is plain that that test rests on the exercise of state judgment, and therefore cannot be here assailed either by disregarding the State's power to judge on the subject, or by testing its motive in enacting the provision.

Id. at 360 .

49. Brief for the United States at 16 , Guinn, 238 U.S. 347 (No. 423 ) ("If the amendment had ended with the first sentence, thereby denying the right to vote to any persons unable to read and write any sections of the State constitution, there would be no question as to its validity.").

5o. Guinn, $23^{8}$ U.S. at $3^{62}$.

51. $\quad l d$. at 366 .

52. Id. at $359-60$ (noting that the United States denied the right "to review or supervise" the state's right to enforce a literacy requirement).

53. Morgan Kousser reads the Court's decision in Guinn not as protective of black voters, but as a mechanism for maintaining white supremacy. Kousser argues that if Justice White wanted to support black political equality, he needed to have overturned Giles $v$. Harris, 189 U.S. 475 (1903). See KoUSSER, supra note 34 , at $473 \mathrm{n.32}$ ("Invalidating the grandfather clause enfranchised no blacks, because that patently unconstitutional device merely allowed illiterate whites to register legally. Throwing out Giles, however, would have allowed blacks to vote, since Giles was a challenge to the administration of the Alabama Constitution. A former member of the 'conservative' faction of the Democratic Party in Louisiana, which had opposed the grandfather clause in that state's constitutional convention in 1898 , White wished to rule that escape clause unconstitutional, but he did not want to endanger white Democratic supremacy in the South."). 
enforce a literacy test because literacy tests did not violate the Fifteenth Amendment.

The Court confirmed Guinn's baseline almost 45 years later in Lassiter $v$. Northampton County Board of Elections, where the Court upheld North Carolina's literacy requirement under the Fourteenth and Seventeenth Amendments.54 Noting that the Guinn Court had resolved the constitutionality of literacy tests "in a few words," 55 the Court's opinion in Lassiter was only slightly more verbose. Justice Douglas, writing for a unanimous Court, stated that " $[\mathrm{t}]$ he states have long been held to have broad powers to determine the conditions under which the right of suffrage may be exercised. ${ }^{6}{ }^{6}$ The Court conceded that the powers of the states are subject to constitutional limits and to "any restriction that Congress acting pursuant to its constitutional powers [may] impose[]." 57 But literacy tests did not violate the Constitution because "[1]iteracy and illiteracy are neutral on race, creed, color, and sex. $5^{8}$ Thus, it followed that Congress lacked the power to prohibit the states from enacting a literacy test.

Less than ten years later and after the VRA became law, the plaintiffs in Katzenbach $v$. Morgan took the same position. They argued that New York could enforce the portion of its election statute that required voters to be able to read and write English, notwithstanding section 4 (e) of the VRA.59 Section $4(e)$ of the VRA prohibits states from denying otherwise qualified individuals the right to vote; it therefore precluded New York from enforcing its Englishliteracy rule. Under the constitutional baseline set by Guinn and confirmed by Lassiter, the plaintiffs and the State of New York should have won the case rather easily. The argument is fairly straightforward. States set the qualifications for voting, and neither the federal government nor the Supreme Court can interfere with a state's chosen voting qualifications unless that state discriminates on the basis of some protected category, such as race. A facially neutral English-literacy requirement is a per se constitutionally valid qualification that is like "[r]esidence requirements, age, previous criminal record,"6o and the literacy tests upheld in Guinn and Lassiter that the Court had found to be within the core function of state governments. Given that the Supreme Court had previously found literacy requirements to be per se constitutional, there was no basis for Congress to prohibit the states from such enactments as it did in section ${ }_{4}(\mathrm{e})$. This was the argument that New York advanced-and lost-in Morgan.

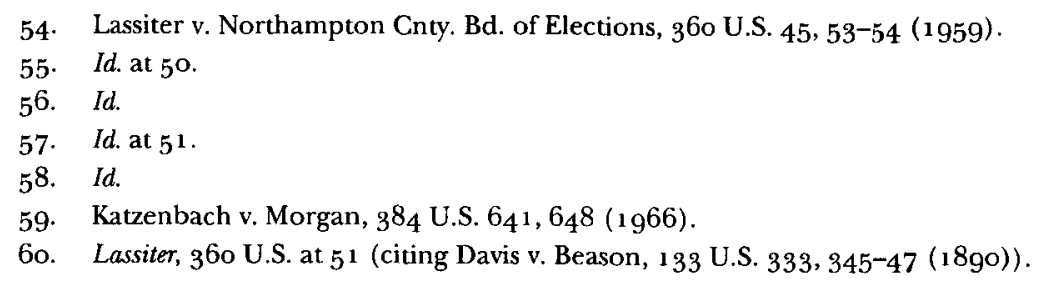


Though the Court in Morgan chanted the received mantra that states establish qualifications for voting and that the only constraint on this power of the states is the Constitution, the Court was interested in a completely different inquiry. The question, the Court stated, was not whether the Court's interpretation of the Fourteenth Amendment precluded New York from promulgating its statute; rather, the question was whether Congress had the power under section 5 of the Fourteenth Amendment to make its own independent determination that the state statute violated the Fourteenth Amendment. ${ }^{6}$ ' In addition, the Court considered whether Congress's judgment that the State violated the Fourteenth Amendment ought to receive great deference from the judiciary. ${ }^{62}$ Notwithstanding the concern about the "federalism costs" of the VRA that would preoccupy the Court in the future, ${ }^{6}{ }_{3}$ the majority in Morgan was willing to defer significantly to Congress's determination that certain state electoral statutes were inconsistent with the Fourteenth Amendment. "It was well within congressional authority to say that this need of the Puerto Rican minority for the vote warranted federal intrusion upon any state interests served by the English literacy requirement." $6_{4}$ Thus, the federalism baseline was moved to the federal government, and its precise location was left to Congress.

Morgan represents how the VRA is a paradigm-shifting statute in three key ways. First, according to the Court in Morgan, Congress is an independent interpreter of the Constitution that need neither wait for the Court to first determine that a state practice has violated the Constitution nor agree with the Court that a state practice does not violate the Constitution before Congress can regulate that state practice. Second, even where the Court disagrees with Congress's interpretation, the Court will provide a fair amount of deference to Congress's interpretation of what state action violates the Fourteenth Amendment. Third, Morgan moved the federalism baseline in favor of the federal government and against the states. While the Court in Guinn placed voting qualifications within the set of core state functions that

61. See Morgan, $3^{8} 4$ U.S. at 649 ("Without regard to whether the judiciary would find that the Equal Protection Clause itself nullifies New York's English literacy requirement as so applied, could Congress prohibit the enforcement of the state law by legislating under [section] 5 of the Fourteenth Amendment?"). In this vein, compare Morgan with the Court's recent decision in Arizona v. Inter Tribal Council of Arizona, Inc., 133 S. Ct. 2247 (2013) (holding that a state proof of citizenship requirement was pre-empted by federal law).

62. Morgan, 384 U.S. at 653 .

63. See, e.g., Nw. Austin Mun. Util. Dist. No. One v. Holder, 557 U.S. 193, 202 (2oog). "These federalism costs have caused Members of this Court to express serious misgivings about the constitutionality of [section] 5." Id. (citing South Carolina v. Katzenbach, $3^{8} 3$ U.S. 301 , $\left.35^{8-62}(1966)\right)$. We discuss the nature of these costs elsewhere. See generally Guy-Uriel E. Charles \& Luis Fuentes-Rohwer, State's Rights, Last Rites, and Voting Rights, 47 CONN. L. REV. 481 (2014); Guy-Uriel E. Charles \& Luis Fuentes-Rohwer, Race, Federalism, and Voting Rights, 2015 CHI. LEGAL F. (forthcoming).

64. Morgan, $3^{8} 4$ U.S. at 653 . 
cannot be regulated by Congress or second-guessed by the federal courts, the Court in Morgan took a different approach. The Morgan Court created room for Congress to determine when it, as opposed to the courts, ought to supervise the states when they enact electoral laws.

The Morgan Court understood that it was not interpreting any ordinary statute. Notwithstanding the Court's prior precedents and prior understanding of the constitutional baselines, the Court molded the prior precedents and moved the constitutional baselines in favor of the VRA because of its magnitude. The Court understood that the VRA was not just an important and effective statute with deep historical significance. Rather, the Court understood the VRA for what it was, a landmark statute promulgated to resolve a fundamental public policy problem. The VRA gave effect to a constitutional command, and it exerted an expressive and interpretive influence beyond its narrow terms. As we will show later, the Court's approach in Shelby County is significantly different from its approach to the VRA in Morgan.

\section{B. COOPERATION}

The second way a statute is eligible for super status is based on the extent that effective implementation of the statute's public policy aims obliges extensive partnership or cooperation between at least two of the three branches. Cooperation is compelled by the fact that the public policy question is sufficiently important, complex, intractable, or contested so that the various branches of government must work together-as more or less equal partners-to find and implement solutions. ${ }^{65}$ This is an institutional account of cooperation and statutory interpretation.

In giving effect to the policy aims of a superstatute, the branches view one another as partners in a joint enterprise. They are not operating from a formal separation-of-powers perspective but from a fluid integration-of-powers mindset. Each branch is self-consciously lending its institutional expertise and prestige in concert with the coordinate branches to address a relevant public policy problem. Note that cooperation has a telos, which is to effectuate the aims of the statute broadly conceived.66

The examples we offer below underscore the importance that our account places on the concept of cooperation. This is the condition that elevates ordinary legislation to super status. In the first Subpart, we contrast

65. Cooperation may be compelled because the statute's great mission convinces the coordinate branches that cooperation is worthwhile, or the branches are ideologically committed to the aim of the statute. It may also be the case that cooperation is compelled because of political constraints. But the underlying point here is that the coordinate branches are willing to partner with Congress to effectuate the purposes of the statute or resolve the pressing public policy problem addressed by the statute.

66. Importantly, as we will argue later, this telos provides a basis for judging the efficacy of superstatutory interpretation. 
the Court's handling of the Civil Rights Act of 1875 with the Court's more recent handling of the Voting Rights Act of $1965 .{ }^{67}$ This discussion makes clear why the 1875 Act never reached super status and the 1965 Act did. The second Subpart illustrates that the Court need not partner only with Congress but may also partner with the executive branch. The common thread that ties all superstatutes together is the willingness on the part of one of the coordinate branches to allow and sometimes invite the other branches to contribute their understanding of the statute and create a collective understanding of the scope and meaning of the statute. Our discussion of the VRA makes clear the Court's willingness to cooperate with the political branches in providing content to the VRA, thereby fulfilling the interbranch cooperation element and making the VRA a superstatute.

\section{Cooperation as Deference to Congress}

The Civil Rights Act of 1875 could have been a superstatute. It was certainly a landmark statute. ${ }^{68}$ Congress passed the Civil Rights Act of 1875 to protect the right of "all persons . . . to the full and equal enjoyment of the accommodations ... of inns, public conveyances on land or water, theaters, and other places of public amusement" regardless of race, color, or previous condition of servitude. ${ }^{69}$ Similar to the VRA, the Civil Rights Act of 1875 was meant to give effect to the Reconstruction Amendments, specifically the Thirteenth and Fourteenth Amendments. The 1875 Act would have removed the de facto mark of slavery that remained even after emancipation and which stained every public interaction between a black citizen and a white merchant. The Act would have afforded citizens the dignity of equal treatment whenever they sought a public accommodation..$^{\circ}$ Moreover, the 1875 Act did not stand alone. Enacted on the heels of the bold, but constitutionally vulnerable, Civil Rights Act of 1866 , the 1875 Act was the latest precarious stepping stone toward a path to full equality for previously bonded servants. The statute was pregnant with possibilities.

But those possibilities required the cooperation of at least one coordinate branch-in this case, the Supreme Court. Unfortunately, the 1875 Act's possibilities as a superstatute were abruptly curtailed in the Civil Rights Cases. The Court took a dim view of Congress's authority to pass the Act and held that Congress did not have the power either under the Fourteenth Amendment or under the Thirteenth Amendment to outlaw private discrimination, even with respect to public accommodations.

67. Compare The Civil Rights Cases, 109 U.S. 3, 13-14 (1883) (displaying the Court's uncooperative posture toward the Civil Rights Act of ${ }_{1875}$ ), with Katzenbach, $38_{3}$ U.S. at 308 (suggesting the Court's more cooperative posture toward the VRA).

68. See ERIC FONER, A SHORT HISTORY OF RECONSTRUCTION, 1863-1877, at 234-35 (1990).

69. Civil Rights Act of 1875 , ch. $114, \S 1,18$ Stat. 335, 336 .

7o. See Jennifer Mason McAward, Defining the Badges and Incidents of Slavery, 14 U. PA. J. CONST. L. 561, 625-26 (2012). 
Justice Bradley's opinion for the Court was an exercise in judicial formalism based upon strict conceptions of separation of powers and federalism. The theory was quite simple: Congress enacts statutes and the Court examines their constitutionality.71 The Court is agnostic about the statute's aims, but strictly polices the constitutional boundaries. $7^{2}$ Following this view, the majority explained that the Fourteenth Amendment did not grant Congress general police powers and " $d[i d]$ not invest Congress with power to legislate upon subjects which are within the domain of State legislation."73 Instead, the Constitution drew clear lines between public rights and private rights, between state action and private action, and between corrective legislation and primary legislation. ${ }^{74}$

This discussion led Justice Bradley to conclude that the Civil Rights Act of 1875 was not properly enacted under the Fourteenth Amendment because the Act regulated private behavior. $75 \mathrm{He}$ reached this conclusion by way of the now-familiar argument that the Fourteenth Amendment only addressed state action, while the 1875 Act sought to reach private action. Similarly, because, in Justice Bradley's words, "the act of a mere individual, the owner of the inn, the public conveyance, or place of amusement, refusing the accommodation, [cannot] be justly regarded as imposing any badge of slavery or servitude upon the applicant," Congress did not properly enact the Act under the Thirteenth Amendment, even though the Thirteenth Amendment applies to private action. $7^{6}$ In concluding the opinion, Justice Bradley and the Court could not help but offer this final piece de resistance that makes explicit their defection from the underlying aim of the Act:

When a man has emerged from slavery, and by the aid of beneficent legislation has shaken off the inseparable concomitants of that state, there must be some stage in the progress of his elevation when he takes the rank of a mere citizen, and ceases to be the special favorite of the laws, and when his rights as a citizen, or a man, are to be protected in the ordinary modes by which other men's rights are protected.77

The Court thereby prevented the Civil Rights Act of 1875 from becoming a superstatute by opting for judicial formalism over cooperation with the political branches. 78

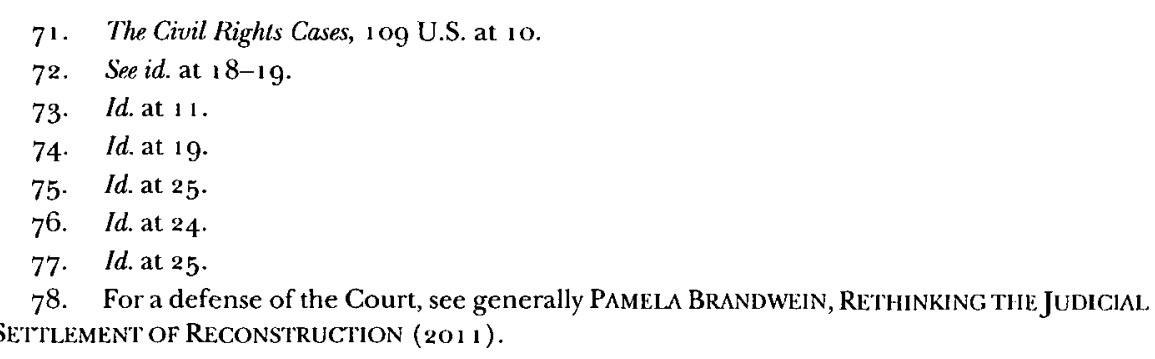


By contrast, the Court could not have been more sympathetic to the aims of the VRA and could not have signaled more its willingness to cooperate with Congress than it did in South Carolina v. Katzenbach. For Chief Justice Warren, who penned the majority opinion in Katzenbach, the constitutionality of the VRA was not to be decided on the basis of a formalistic and rigid understanding of both the statute and the Constitution, but "with reference to the historical experience which it reflects."79 The Court clearly viewed Congress as a partner in resolving the problem of racial discrimination in voting that had plagued (and notice the personalization of the problem) "our country for nearly a century." 80 With respect to the powers of Congress, this time under the Fifteenth Amendment, the Court was unequivocal:

The language and purpose of the Fifteenth Amendment, the prior decisions construing its several provisions, and the general doctrines of constitutional interpretation, all point to one fundamental principle. As against the reserved powers of the States, Congress may use any rational means to effectuate the constitutional prohibition of racial discrimination in voting. ${ }^{81}$

The Court explicitly rejected "any . . . artificial rules" that would "circumscribe[]" the powers of Congress. ${ }^{82}$ Contrary to the Court's approach in the Civil Rights Cases, an approach that dissented from and refused to cooperate with the vision of racial equality put forward by Congress in the Civil Rights Act of 1857 , Chief Justice Warren and the majority in Katzenbach explicitly embraced the aims of the VRA and constitutionalized that vision, quoting the Fifteenth Amendment:

We here hold that the portions of the Voting Rights Act properly before us are a valid means for carrying out the commands of the Fifteenth Amendment. Hopefully, millions of non-white Americans will now be able to participate for the first time on an equal basis in the government under which they live. We may finally look forward to the day when truly " $[\mathrm{t}]$ he right of citizens of the United States to vote shall not be denied or abridged by the United States or by any State on account of race, color, or previous condition of servitude." ${ }_{3}$

South Carolina v. Katzenbach is of a piece with Katzenbach $v$. Morgan, both of which were decided in the same term. Recall that, notwithstanding the fact the Court in Lassiter held that literacy tests were constitutional, the Morgan Court upheld a provision of the VRA that outlawed literacy tests. ${ }^{8_{4}}$ Morgan

79. South Carolina v. Katzenbach, 383 U.S. 301,308 ( 1966 ).

8o. Id. (emphasis added).

8. . $I d$. at 324 .

82. Id. at 327 .

83. Id. at 337 (alteration in original).

84. See supra notes $59-65$ and accompanying text. 
clearly depended upon a partnership and an aggregation-of-powers framework and not a principal-agent separation-of-powers framework. The Court, therefore, was creating the constitutional space necessary to enable Congress to resolve what the Court recognized as a difficult and pressing problem. In a move that turned the separation-of-powers and the principalagent model on its head, the Court deferred to Congress's vision of constitutional equality, notwithstanding the fact that that vision contradicted and displaced the Court's previously articulated understanding of constitutional equality. This is a common move in the VRA cases. When the Court analyzes the VRA, its deference to Congress is evidence of the interbranch cooperation that befits a superstatute.

\section{Cooperation as Deference to the Executive Branch}

In interpreting superstatutes-and the VRA specifically-the Court's deference and cooperation is not limited to Congress. It also extends to the executive branch. Consider the case of Georgia v. United States. There, the State of Georgia objected, inter alia, to the administrative regulations the Attorney General promulgated in implementing the VRA. ${ }^{8} \overline{5}$ In particular, Georgia argued that the Attorney General did not have the authority to adopt regulations that shifted the burden of proving that a proposed change was enacted without a discriminatory purpose or effect to covered jurisdictions. ${ }^{86}$ The Attorney General objected to Georgia's legislative reapportionment plan because he was "unable to conclude that the plan does not have a discriminatory racial effect on voting. ${ }^{8} 7$ Georgia contended that the Attorney General could not object on that basis. Georgia argued that the Attorney General had to first conclude that the plan had a racially discriminatory purpose or effect before refusing to preclear it. ${ }^{88}$

The Court disagreed. Though it acknowledged the fact "that [section] 5 itself does not authorize the Attorney General to promulgate any regulations," it nevertheless concluded that the regulations were permissible. ${ }^{89}$ The critical inquiry for the Court was whether the regulations adopted by the Attorney General were reasonable, the most deferential standard of review. Finding that the regulations were reasonable, the Court applauded the Attorney General's regulations as "lawful and effective." ${ }^{\circ}$

Note the Morgan-like radicalness of the Court's decision in Georgia, a radicalness that the sands of time should not obscure. From a federalism perspective, it is one thing for Congress to shift the burden of proof to the

\footnotetext{
85. Georgia v. United States, 411 U.S. 526,531 (1973).

86. Id.

87. Id. at $53^{\circ}$ (internal quotation marks omitted).

88. Id. at 531 .

89. Id. at 536 .

9o. Id. at 539 .
} 
covered jurisdictions when those jurisdictions are instituting a declaratory judgment action in federal court. It is another thing altogether for the Attomey General, on his own, to shift the burden of proof to the covered jurisdictions and for the Court to defer to this unilateral act. Justice White hinted at this problem in his dissenting opinion:

Although the constitutionality of [section] 5 has long since been upheld, it remains a serious matter that a sovereign State must submit its legislation to federal authorities before it may take effect. It is even more serious to insist that it initiate litigation and carry the burden of proof as to constitutionality simply because the State has employed a particular test or device and a sufficiently low percentage of its citizens has voted in its elections. And why should the State be forced to shoulder that burden where its proposed change is so colorless that the country's highest legal officer professes his inability to make up his mind as to its legality? If he is to object, must he not himself conclude that the proposed change will have the forbidden purpose or effect?91

Georgia became one of the most important, if not the most important, legal authorities available to the Attorney General in interpreting the VRA. It enabled the DOJ to hold a Damoclean sword over the covered jurisdictions. The DOJ cited the case in almost every objection letter that it sent to submitting parties as a reminder of its authority, now supported not just by its regulations, but also by the authority of the Supreme Court. $9^{2}$

In addition, Georgia was an important case because the Court showed a willingness to defer to the Attorney General not only with respect to administrative regulations, but also with respect to the Attorney General's substantive interpretation of the Act itself. Most importantly for our purposes, however, is the fact that Georgia was not an outlier. Four years later, in United States $v$. Sheffield Board of Commissioners, the Court decided whether section 5 preclearance applied to the City of Sheffield, a political unit within the covered State of Alabama.93 The statutory language could not be any clearer: only states and political subdivisions are subject to section 5 , and political subdivisions are counties or parishes, or else jurisdictions that conduct voter registration.94 Sheffield was not a political entity that conducted voter

91. Id. at 543-44 (White, J., dissenting) (citation omitted); see also id. at 545 (Powell, J., dissenting) ("As a minimum, assuming the constitutionality of the Act, the Attorney General should be required to comply with it explicitly and to invoke its provisions only when he is able to make an affirmative finding rather than an ambivalent one.").

92. See Luis Fuentes-Rohwer \& Guy-Uriel E. Charles, Preclearance, Discrimination, and the Department of fustice: The Case of South Carolina, 57 S.C. L. REv. 827, 857-58 (2006).

93. United States v. Sheffield Bd. of Comm'rs, 435 U.S. 110,113 (1978).

94. See 42 U.S.C. $\$ 1973 l(\mathrm{c})(2)$ (2012) ('The term 'political subdivision' shall mean any county or parish, except that where registration for voting is not conducted under the supervision 
registration. Therefore, the city argued that, according to the clear language of the statute, it was not required to preclear its proposed changes.

In response, the Court once again looked to the Attorney General:

What is perhaps a more compelling argument concerning the original, and subsequent, congressional understanding of the scope of [section] 5 is that the Attorney General has, since the Act was adopted in 1965 , interpreted [section] 5 as requiring all political units in designated jurisdictions to preclear proposed voting changes. ... In recognition of the Attorney General's key role in the formulation of the Act, this Court in the past has given great deference to his interpretations of it. 95

This was a consistent theme through the years. In Dougherty County Board of Education $v$. White, plaintiffs raised a similar issue with respect to the scope of section 5 . Once again, relying upon the Attorney General's interpretation, the Court noted that in light of "the central role of the Attorney General in formulating and implementing [section] 5 , [his] interpretation of its scope is entitled to particular deference." ${ }^{6}$ Similarly, in NAACP v. Hampton County Election Commission, the Court once again invoked the Attorney General's interpretations of the VRA as determinative proof of the Act's meaning. In that case, the Court decided whether a statute authorizing a school board election had to be precleared. The Court stated that "[a]ny doubt that these changes are covered by [section] 5 is resolved by the construction placed upon the Act by the Attorney General, which is entitled to considerable deference." 97

A superstatute, then, is landmark legislation that requires the branches to work as partners in order to effectuate the legislation's purpose. Under this definition, the VRA is clearly a superstatute. But to so argue only begins the inquiry. As the next Part explains, once a statute is identified as a superstatute, the underappreciated question of superstatutory interpretation immediately arises.

of a county or parish, the term shall include any other subdivision of a State which conducts registration for voting.").

95. Sheffield Bd. of Comm'rs, 435 U.S. at 131.

96. Dougherty Cnty. Bd. of Educ. v. White, 439 U.S. 32,39 (1978).

97. NAACP v. Hampton Cnty. Election Comm'n, 47 o U.S. 166, $178-79$ (1985). Contrast the Court's decisions in Dougherty County and Hampton County with its decision ten years later in Miller y. Johnson, in which the Court excoriated the Department of Justice for, in the Court's view, trying to unconstitutionally maximize majority-minority districts. See generally Miller v. Johnson, 515 U.S. 900 (1995). Unlike in Dougherty County and Hampton County, where the Court viewed the DOJ as an entity entitled to deference, in Miller the Court viewed the DOJ not as an equal partner but as a subordinate. See id. at 922 ("We do not accept the contention that the State has a compelling interest in complying with whatever preclearance mandates the Justice Department issues. When a state governmental entity seeks to justify race-based remedies to cure the effects of past discrimination, we do not accept the government's mere assertion that the remedial action is required. Rather, we insist on a strong basis in evidence of the harm being remedied."). 


\section{PRAGMATIC INTERPRETATION}

Treating the VRA like a superstatute is particularly consequential for the pragmatic way in which the Court has interpreted the Act over the years. The Court has interpreted the statute pragmatically both to expand the scope of the Act generally while also narrowing its scope, especially against the backdrop of constitutional concerns. The evolution of the Act, in fact, offers a prototypical example of Ronald Dworkin's chain-letter analogy. According to Dworkin, a statutory interpreter "see[s] his own role as fundamentally the creative one of a partner continuing to develop, in what he believes is the best way, the statutory scheme Congress began. ${ }^{n 8}$ This Part situates the recent and largely misunderstood case of Northwest Austin within the chain letter the VRA created.

\section{A. NORTHWEST AUSTIN AS A CHAIN LETTER}

Soon after Congress renewed section 5 's preclearance requirement for another 25 years in 2006,99 the Northwest Austin Municipal District Number One (the "District"), a small utility district located in Travis County, Texas, filed suit challenging Congress's constitutional power to compel covered jurisdictions to preclear proposed changes. ${ }^{100}$ Because the District is located in Texas, a covered jurisdiction, it had to preclear any changes to votingrelated procedures or practices with the DOJ or the United States District Court for the District of Columbia before it could implement them. ${ }^{101}$ Though the District is ultimately responsible for voter registration, it does not conduct its own elections, which it delegates to Travis County for administrative reasons. ${ }^{102}$ The District also argued, on statutory grounds, that it should be permitted to "bailout" from the preclearance requirement because it had never engaged in racial discrimination notwithstanding the fact that it is located in Texas, a covered jurisdiction that has engaged in racial discrimination in voting.

A three-judge panel at the district court rejected both the constitutional and the statutory challenges. ${ }^{103}$ The Supreme Court reversed and concluded

98. RONALD DWORKIN, LAW'S EMPIRE 313 (1986); see also Ronald Dworkin, Law as Interpretation, 6o TEX. L. REV. 527, 541-43 (1982). For an empirical critique of Dworkin's argument, see Stefanie A. Lindquist \& Frank B. Cross, Empirically Testing Dworkin's Chain Novel Theory: Studying the Path of Precedent, 80 N.Y.U. L. REV. 1156, 1205 (2005) (discussing the results of their study, which revealed "that judicial discretion appears to expand with the growth of additional precedents").

99. Fannie Lou Hamer, Rosa Parks, and Coretta Scott King Voting Rights Act Reauthorization and Amendments Act of $2006 \S \S 4-5,4^{2}$ U.S.C. $\S \S 1973^{b-1973 c ~(2012) . ~}$

10o. Nw. Austin Mun. Util. Dist. No. One v. Holder, 557 U.S. 193, 197 (2009).

101. Id. at 200 .

102. Id.

103. Id. at 201. 
that the District was statutorily eligible for bailout from section 5 coverage. ${ }^{104}$ Under the clear terms of the statute, only those political subdivisions that conduct registration for voting are eligible for bailout. ${ }^{10}$ The lower court in Northwest Austin found that because the District was not a county or parish and did not conduct registration for voting, it was not eligible for bailout under section 4 (a) . ${ }^{106}$ It was also the conclusion of most voting rights scholars prior to the Supreme Court's decision. ${ }^{107}$

Yet, the Court understood the statute differently. ${ }^{108}$ Not one single justice agreed with the district court despite the clear language of section $14(\mathrm{c})(2)$. Writing for the majority, Chief Justice Roberts began with the proposition that "[s] tatutory definitions control the meaning of statutory words, of course, in the usual case. But this is an unusual case." 109 The District's case was unusual, Chief Justice Roberts reasoned, not because the statutory text is ambiguousindeed the text is crystal clear-but because "specific precedent, the structure of the Voting Rights Act, and underlying constitutional concerns compel a broader reading of the bailout provision." ${ }^{10}$ In other words, the fact that the statutory text is unambiguous is not a sufficient justification to accord the text its plain meaning. Statutory meaning is not determined by the plain meaning of an unambiguous text; other considerations trump.

Chief Justice Roberts relied upon two cases to support the proposition that the text need not determine its interpretation of the statute: United States v. Sheffield Board of Commissioners and Dougherty County Board of Education v. White. In order to understand the Court's statutory interpretation in Northwest Austin, we must first make sense of these two cases.

In Sheffield, the Alabama city changed its governance structure from a commission system-in which three commissioners ran city operations-to a

104. Id. at 211 . Bailout is governed by section 4 of the VRA. Section 4 (a) allows a state or political subdivision to bailout from coverage if the state or political subdivision obtains a declaratory judgment from the United States District Court for the District of Columbia that it has a record of compliance with the VRA. $4^{2}$ U.S.C. $\$ 1973$ b(a) (1) (2012).

105. By definition, counties or parishes are political subdivisions under the statute; they need not conduct registration for voting.

106. Nw. Austin Mun. Util. Dist. No. One v. Mukasey, 573 F. Supp. 2d 221, 283 (D.D.C. 2008), rev'd sub nom. Nw. Austin Mun. Util. Dist. No. One v. Holder, 557 U.S. 193.

107. See Heather K. Gerken, The Supreme Court Punts on Section 5, BALKINIZATION (June 2 2, 2009, 10:42 AM), http://balkin.blogspot.com/2009/o6/supreme-court-punts-on-section-5.html ("[T] he statutory argument is one that almost no one (save Greg Coleman, the lawyer who argued the case and who is now entitled to be described as a mad genius) thought was particularly tenable because of prior Court opinions."); Richard L. Hasen, Sordid Business: Will the Supreme Court Kill the Voting Rights Act?, SLATE (Apr. 27, 2009, 1 1:59 AM), http://www.slate.com/id/2216888/ ("Since there's no good statutory loophole, the larger constitutional question seems unavoidable.").

108. For a discussion and critique, see generally Richard L. Hasen, Constitutional Avoidance and Anti-Avoidance by the Roberts Court, 2009 SUP. CT. REV. 181.

109. Nw. Austin, 557 U.S. at 206-07 (quoting Lawson v. Suwannee Fruit \& S.S. Co., 336 U.S. 198,201 (1949)) (internal quotation marks omitted).

1 10 . Id. at 207. 
mayor-council system."' Under the new system, council members would be elected at large. ${ }^{112}$ The Attorney General objected to the new means of election and sought a temporary restraining order against the City of Sheffield. Even though the entire state of Alabama was a covered jurisdiction, Sheffield argued that it was not required to preclear the change because it was not a political subdivision conducting registration for voting, as defined in section $14(\mathrm{c})(2) .{ }^{113}$ The district court agreed. ${ }^{14}$ Accordingly, the Court concluded, once section 4 covered a state, section 5 only subjected to the preclearance requirement those political subdivisions that conducted voter registration.

This was not an unreasonable understanding of the statutory scheme and the concerns that guided the 8gth Congress. Looking to the facts at hand in $196_{5}$, Congress was clearly concerned with access to the ballot for voters of color. Registration thus stood at the heart of the VRA. Consequently, only those subdivisions entrusted with registration authority would be subject to the coverage and preclearance provisions.

The Supreme Court disagreed with this reading of the statute. Justice Brennan, writing for the majority, maintained that the lower court's conclusion was "inconsistent" with the structure of the Act and the purpose of the law. ${ }^{15} \mathrm{He}$ grounded his holding in an anti-circumvention rationale. To read the statute as the district court read it would permit covered states to defeat the purpose of the statute by devolving political power to local authorities and empowering them to "take steps that would, temporarily at least, dilute or entirely defeat the voting rights of minorities." 16 Covered states could "circumvent the Act . . . by allowing local entities that do not conduct voter registration to control critical aspects of the electoral process." 117 This would undermine the very purpose and structure of the Act, a chief aim of which was to prevent local officials from staying one step ahead of regulators. In the Court's words, “ $[t]$ he clear consequence of this interpretation would be to nullify both [section] 5 and the Act in a large number of its potential applications." ${ }_{118}$ This was the reason that section 5 attempted to freeze all "procedure[s] with respect to voting" until they were precleared." $" 19$

111. United States v. Sheffield Bd. of Comm'rs, 435 U.S. $110,114^{-15}$ (1978).

112. Id. at 115 .

113 . Id. at 116.

114 . See United States v. Sheffield Bd. of Comm'rs, 430 F. Supp. 786,789 (N.D. Ala. 1976), rev'd, 435 U.S. $110(1978)$ ("This Court is of the opinion that the City of Sheffield is not covered by the Voting Rights Act of $1965 . "$ ).

115 . Sheffield, 435 U.S. at $117^{-18}$.

116. Id. at 124 .

117. Id. at 125 .

118. Id.

119. Id. at 122 
Justice Brennan's argument had much to commend it but for one obvious fact: the clear language of the Act appeared to pose an insurmountable obstacle. Only political units that registered voters were subject to section 5 , and the City of Sheffield clearly did not register anyone. According to Justice Brennan, however, section 14(c)(2) did not have any bearing on and was, in fact, irrelevant to understanding the scope of section $5 .{ }^{120}$ To his mind, the legislative history of section $14(\mathrm{c})(2)$ made clear that this statutory definition was only applicable to areas outside covered states. ${ }^{121}$ In other words, once a state has been designated for coverage, section 14 (c) (2) "has no operative significance in determining the reach of [section] $5 \ldots{ }^{122}$ Section $14(\mathrm{c})(2)$ is inapplicable when the question is whether a non-designated political unit in a covered state is required to preclear changes related to voting. For Justice Brennan and the majority, "the legislative history [left] no doubt but that it is in this sense that Congress used the term."123

The Court endorsed Sheffield's anti-circumvention rationale in Dougherty County Board of Education $v$. White. ${ }^{124}$ The Dougherty County Board of Education, a political unit within the State of Georgia-a covered stateadopted a rule that required any employee seeking political office to take a leave of absence without pay. ${ }^{125}$ As it happened, the County adopted the rule after the plaintiff, an African-American employee of the school board, announced his candidacy for the Georgia House of Representatives. The plaintiff ultimately filed suit on the ground that the school board failed to preclear the rule, in violation of section 5 of the Act. ${ }^{126}$ As a subdivision located in a covered jurisdiction, the plaintiff argued, changes related to voting required preclearance. ${ }^{127}$ The school board argued, inter alia, that it was not a covered jurisdiction as that term was defined under section 14 (c) (2) -it was not a county or parish, and it did not register voters. ${ }^{128}$

The Supreme Court disagreed with the school board. Writing for the majority and echoing the Court's opinion in Sheffield, Justice Marshall explained that "[section] 5 requires preclearance whenever a political subdivision within a covered State adopts a change in a standard, practice, or procedure with respect to voting. No requirement that the subdivision itself

1 20. See id. at $126-27$.

121. See id. at 128 ("The legislative background of [section] 14 (c) (2)'s definition of "political subdivision' reflects that Congress intended to define [the term] 'political subdivision' as areas of a nondesignated State.").

122. Id. at 126 ; see also $i d$. at 127 ("But it is clear that once a State is designated for coverage the Act's remedial provisions apply to actions that are not formally those of the State.").

123. Id. at 128 n.15.

124. See Dougherty Cnty. Bd. of Educ. v. White, 439 U.S. 32, 44-45 (1978).

125 . Id. at 34 .

126 . Id. at 35 .

127. Id.

128. Id. at $43-44$. 
conduct elections is stated in [section] 5 and none is fairly implied."129 Justice Marshall rested his holding on Sheffield's anti-circumvention rationale. He noted that a contrary decision "would enable covered jurisdictions to circumvent the Act by delegating power over candidate qualification to local entities that do not conduct elections or voter registration." ${ }_{180}$ This is a result that "Sheffield sought to avert."191

From a doctrinal standpoint, we could argue quite persuasively that Sheffield and Dougherty County were inapposite and distinguishable from Northwest Austin. First, these are preclearance cases and not bailout cases. ${ }^{192}$ They are directed toward a different set of concerns than those addressed by the Court in Northwest Austin.

Second, the Court's opinions in Sheffield and Dougherty County were justified by an anti-circumvention rationale that is not present in Northwest Austin. Sheffield and Dougherty County are VRA-enhancing cases. The Court's worry in both cases was that state and local jurisdictions would collude to circumvent the applicability of the VRA. Congress's concern with the ability of local officials to stay one step ahead of regulation was the reason for the elaborate mechanisms of the VRA in the first place.138 The Court's statutory interpretation in Sheffield and Dougherty County intended to strengthen and expand the reach of the VRA. In contrast, Northwest Austin is a VRA-limiting case. Its statutory interpretation is intended to restrict the scope of the VRA.

Third, and perhaps most importantly, in Northwest Austin, a clear and unambiguous text applied to the problem before the Court. Section 14 (c) (2) was squarely on point. This was not the case in Sheffield and Dougherty County. One could argue that the Court in those two cases was choosing between two equally applicable interpretations of the statutory text. Consequently, the Court's interpretation of the statutory text in both cases did less violence to that text than the Court's interpretation in Northwest Austin.

But to focus on these putative doctrinal inconsistencies would be to miss the Court's larger lesson in Northwest Austin. The Chief Justice's larger point is that when it comes to the VRA, the text is, at best, a jumping-off point for making voting rights policy. Given that the Court has never allowed the plain meaning of an unambiguous text to cabin its interpretation, the Chief Justice

\footnotetext{
129. Id. at 45 .

130. Id.

131. Id.

132. See, e.g., City of Rome v. United States, 446 U.S. 156, 168-69 (1980) (considering the legislative intent behind the bailout provision and concluding that the City could not seek bailout).

133. Indeed, even Justice Powell, who raised significant questions with respect to the constitutionality of the Act in Allen v. State Board of Elections, concurred in Sheffield on the ground that the decision was "necessary in order to effectuate the purposes of the Act" because a contrary holding would enable a covered State or political subdivision to "achieve through its instrumentalities what it could not do itself without preclearance." United States v. Sheffield Bd. of Comm'rs, 439 U.S. 110,139 (1978) (Powell, J., concurring). Though Justice Powell went on to dissent in Dougherty County, Justice Marshall picked up Justice Stevens's vote, a dissenter in Sheffield.
} 
reasoned in Northwest Austin, why start now? This has been true from the moment the Court first considered the substantive meaning of the VRA. This was Allen v. State Board of Elections. ${ }^{134}$

\section{B. THE BEGINNING: ALLEN}

Allen is well-known for the Court's substantive interpretation of the VRA. ${ }^{195}$ It is less well-known for the Court's interpretation of a number of preliminary jurisdictional issues, which are at least as consequential as the substantive questions. First, the Court needed to determine whether private plaintiffs were entitled to bring enforcement actions under section 5 . Second, the Court had to address whether all lawsuits under section 5 must be brought in the United States District Court for the District of Columbia. Third, the Court was compelled to resolve whether three-judge courts should hear lawsuits under section 5 . The future effectiveness of the Act hung in the balance.

\section{The Act and Private Attorneys General}

The Court's first statutory question was whether the VRA authorized private plaintiffs to seek a declaration that a state has implemented a change related to voting without first preclearing the change, as required by section 5. As a textual matter, the plaintiffs could not argue that the VRA permitted them to act as private attorneys general. No provision in the text of the VRA authorizes private plaintiffs to file enforcement actions. At best one could say that the text was silent. Moreover, if one examined the statutory scheme holistically, the best answer was that the VRA delegated the exclusive authority to public officials, and specifically the DOJ, to bring enforcement actions.

In an expansive interpretation of the statute, the Court ruled otherwise. Acknowledging that the question could not be resolved textually, the Court found refuge in pragmatic considerations and the purpose of the Act. ${ }^{136}$ Citing its landmark opinion in South Carolina $v$. Katzenbach, the Court concluded that the Act's major purpose was "to make the guarantees of the Fifteenth Amendment finally a reality for all citizens." 137 The guarantee of racial equality, the Court noted, was explicitly provided by section 5 . To depend solely on the Attorney General and her discretion in enforcing

\footnotetext{
134. The Court had concluded in South Carolina v. Katzenbach that the Act was constitutional, but it was not until Allen that the Court first interpreted the Act. See Allen v. State Bd. of Elections, 393 U.S. 544, 548 (1 969$)$.

135. See, e.g., ABIGAil M. Thernstrom, WhOSE Votes Count? AFFirmative ACTION AND MINORITY VOTING RIGHTS 22-24 (1987).

136. Allen, 393 U.S. at 554-55 ("The Voting Rights Act does not explicitly grant or deny private parties authorization to seek a declaratory judgment that a State has failed to comply with the provisions of the Act.").
}

137. Id. at $55^{6}$. 
section 5 of the Act, however, could hamper this goal. ${ }^{13^{8}}$ This was because the Attorney General, with her limited staff, could not be expected to uncover the many voting changes that took place at all levels of government.139 Consequently, the Court concluded that "[i]t [was] consistent with the broad purpose of the Act to allow the individual citizen standing to insure that his city or county government complies with the [section] 5 approval requirements." ${ }^{\circ} 4^{\circ}$ Pragmatic considerations trumped a textual analysis.

\section{Private Attorneys General and Local Federal Courts}

The Court then turned to the second statutory interpretation question, which was premised upon the first: if private plaintiffs could file section $\mathbf{5}$ enforcement actions, could they file these actions in the local district court? Or else, must these actions be filed in the District Court for the District of Columbia? Unlike the first question, where the text was silent, here the text of the Act appeared to offer a clear answer. Section 14 (b) provided that “ [n]o court other than the District Court for the District of Columbia shall have jurisdiction to issue any declaratory judgment pursuant to section [4] or $[5]$... or any restraining order or temporary or permanent injunction against the execution or enforcement of any provision of [this Act]."14' This was as clear and definitive an answer for exclusive jurisdiction of enforcement actions under section 5 as Congress could draft. Or so it appeared.

The problem for the Court was this: if the Court was right that private attorneys general were crucial in enforcing the Act's guarantees, could these individuals be expected to bring these claims in the District Court for the District of Columbia, as opposed to the local federal district courts where the potential plaintiffs resided? The answer was clearly no. If private attorney generals were crucial to the enforcement of the Act, then forcing them to file suit in the District Court for the District of Columbia was counter to that objective. Chief Justice Warren and the majority in Allen appreciated this dilemma. But the issue was how to deal with the clear statutory language.

According to the Court, section $14^{\text {(b) }}$ cannot be read in isolation..$^{14^{2}}$ It was true that section 14 (b) granted exclusive jurisdiction to the District Court for the District of Columbia.'43 But this jurisdiction was for a particular

138. Id. (explaining that this "laudable goal could be severely hampered ... if each citizen were required to depend solely on litigation instituted at the discretion of the Attorney General").

139. Id. ("The Attorney General has a limited staff and often might be unable to uncover quickly new regulations and enactments passed at the varying levels of state government.").

1 40. Id. at 557. "The guarantee of [section] 5 that no person shall be denied the right to vote for failure to comply with an unapproved new enactment subject to [section] 5 , might well prove an empty promise unless the private citizen were allowed to seek judicial enforcement of the prohibition." Id. The Court also noted that allowing a private cause of action under section 5 is consistent with past practice and precedent. Id.

141. 42 U.S.C. $\$ 1973 l$ (b) (2012).

142. Allen, 393 U.S. at $55^{8}$.

143. Id. at $557-5^{8}$. 
purpose: to entertain suits "against the execution or enforcement of any provision of [this Act]." 144 These suits would, of necessity, involve a constitutional attack on the Act. ${ }^{145}$ As such, they must be heard by the District Court for the District of Columbia.

In contrast, section 12 (d) of the Act authorizes the Attorney General to seek an injunction, among other remedies, against anyone who has violated or is about to violate the Act. ${ }^{14^{6}}$ In turn, section 12 (f) provided federal district courts with jurisdiction over suits instituted under section $12(d) .^{147}$ To be sure, section 12 (d) and (f) were grants of power to the Attorney General. To the Court, however, the crucial fact was "that [section] 12 (f) ... [wa]s aimed at prohibiting the enforcement of a state enactment that is for some reason violative of the Act." ${ }^{4}{ }^{8}$

The same reasoning applied when considering declaratory judgment suits, the Court found. ${ }^{149}$ Congress must have provided exclusive jurisdiction to the District Court for the District of Columbia to hear what it termed "substantive discrimination" questions and concomitant constitutional challenges from plaintiffs, who are likely to be state officials hostile to the enforcement of the VRA..$^{\circ}$ Conversely, universal jurisdiction was available to plaintiffs, who are likely to be voters of color, when they are trying to institute coverage suits against hostile state statutes or regulations. ${ }^{151}$

To the Court, policy considerations strongly counseled for its preferred view:

Requiring that declaratory judgment actions be brought in the District of Columbia places a burden on the plaintiff. . . Admittedly, it would be easier for States to bring [section] 5 actions in the district courts in their own States. However, the State has sufficient resources to prosecute the actions easily in the Nation's Capital . . . . On the other hand, the individual litigant will often not have sufficient resources to maintain an action easily outside the district in which he resides, especially in cases where the individual litigant is attacking a local city or county regulation. Thus, for the individual litigant, the District of Columbia burden may be sufficient to preclude him from bringing suit. ${ }^{15^{2}}$

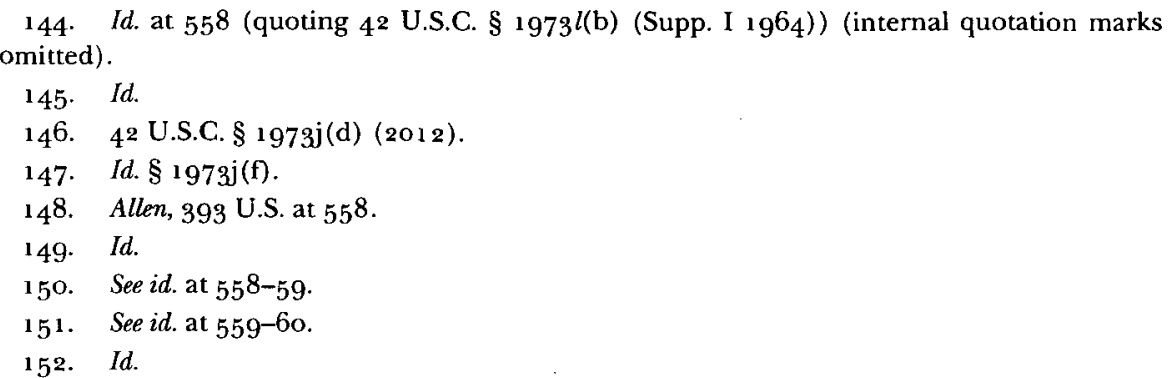


The Court concluded that the plaintiffs could file suit in their local federal district court because section 14 (b) applied only to declaratory judgment actions brought by a state and not to a declaratory judgment action brought by private litigants. ${ }^{153}$ And once again, the Court preferred pragmatic considerations despite seemingly contrary statutory language.

\section{Local Three-Judge Courts}

The third jurisdictional statutory interpretation question was whether three-judge panels should hear lawsuits filed by private litigants. While the Act clearly provided for three-judge panels to hear lawsuits brought by the state or by the U.S. Attorney General, the Act did not address the availability of three-judge panels for suits brought by private litigants. Unsurprisingly, the VRA was silent on the issue as the VRA did not specifically authorize private litigants to bring suit under the Act in the first place.

Having authorized private causes of action, the Court's decision on threejudge panels was almost preordained. Drawing on the legislative justification for permitting three-judge panels in the types of cases the statute specifically contemplated, the Court noted that "Congress has determined that threejudge courts are desirable in a number of circumstances involving confrontations between state and federal power or in circumstances involving a potential for substantial interference with government administration."154 According to the Court, the VRA fits within this general purpose. In the VRA, " $[\mathrm{t}]$ he clash between federal and state power and the potential disruption to state government are apparent." 155 This clash is no less significant when the lawsuit is filed by private individuals because "the potential for disruption of state election procedures remains." ${ }^{5} 5^{6}$ Consequently, the Court "conclude[d] that in light of the extraordinary nature of the Act in general, and the unique approval requirements of [section] 5 , Congress intended" to provide for the availability of three-judge panels to adjudicate section 5 coverage disputes. ${ }^{157}$

153. Id. at 559. Section 12 (f), which the Court used as the textual hook for finding a right to a private enforcement action, is clearly a particularized exception to section 14 (b)'s requirement that only "the District Court for the District of Columbia . . . ha[s] jurisdiction to issue any declaratory judgment pursuant to section [2] or [5]." 42 U.S.C. $\$ 1973 l$ (b) (2012). Section 12 (d) authorizes the Attorney General to file suit "[w]henever any person has engaged or there are reasonable grounds to believe that any person is about to engage in any act or practice prohibited by [the VRA]." Id. $\$ 1973 \mathrm{j}(\mathrm{d})$. Similarly, section 12 (e) authorizes the Attorney General to file suit when federal-election examiners notify the Attorney General that eligible voters were not allowed to vote. $I d$. $\S 1973 \mathrm{j}(\mathrm{e})$. Thus, when section $12(\mathrm{f})$ explicitly refers to "proceedings instituted pursuant to this section," the context for that reference is not a general grant of jurisdiction to the federal courts, but a grant of jurisdiction to address specifically the provisions of section 12. Id. $\S 1973 \mathrm{j}(\mathrm{f})$.

154. Allen, 393 U.S. at $\mathbf{5}^{62}$.

155. Id.

156. Id. at $5^{63}$.

157. Id. 
And facing yet another issue on which the Act was silent, the Court again provided a pragmatic interpretation.

Chief Justice Roberts's assertion in Northwest Austin - that the Court has often departed from the text of the VRA to effectuate what the Court believes is a proper policy outcome-is supported by our analysis of Allen. In Allen, the Court, in effect, amended the VRA to provide for private enforcement actions. It then determined which court would have jurisdiction of those actions. Next, it concluded that those actions were best heard by three-judge panels with direct appeal to the Supreme Court. Fundamentally, none of those policy judgments were dictated or supported by the text of the VRA. Note that these were the preliminary jurisdictional interpretations of the statute in Allen. For many, the more radical statutory judgments in Allen are the Court's substantive interpretation of the statute..$^{158}$

When one examines Northwest Austin, Allen, and the vast majority of voting rights cases, it is clear that the Court approaches its interpretation of the VRA differently than it does other statutes. Underlying Chief Justice Roberts's statutory reasoning is the assumption that the VRA is not ordinary legislation. The Court has often departed from the text of the VRA, even where the text is clear, to give effect to what it believes are the underlying public policy values that should determine the role of race in electoral politics. ${ }^{159}$ The Court has felt free to take liberties with the text of the statute that it would not take with an ordinary statute. Statutory interpretation in the context of the VRA exhibits an interpretive elasticity that functionally amends the statute to comport with the Court's understanding of the statute's proper policy aims. ${ }^{160}$ The Court has used its statutory interpretation of the VRA to fill in significant statutory gaps and to update the VRA so that it responds to present-day realities.

The scholarly commentary that followed Northwest Austin criticized the Court's conclusion. But this is mostly a failure to appreciate the Act's evolution and the Court's pragmatic interpretations of its vague language. The more interesting inquiry considers the Court's recent handling of the Act, and particularly the way that it refused to continue to update the Act in

158. Id. at $5^{66}$ (concluding that " $[\mathrm{t}]$ he legislative history ... supports the view that Congress intended to reach any state enactment which altered the election law of a covered State in even a minor way").

159. See Luis Fuentes-Rohwer, Understanding the Paradoxical Case of the Voting Rights Act, 36 Fl.A. ST. U. L. Rev. 697, 750-51 (2009).

16o. The VRA is not unique; commentators have identified at least one other statute-the Sherman Antitrust Act-that reflects a similar interpretive elasticity. See Margaret $\mathrm{H}$. Lemos, The Other Delegate: Judicially Administered Statutes and the Nondelegation Doctrine, 81 S. CAL. L. REV. $4^{\circ} 5$, $462(2008)$. 
Shelby County. ${ }^{161}$ How do we explain, in other words, the looming death of the VRA, long considered a superstatute? This is the burden of the next Part.

\section{DISSENSUS}

Superstatutes are not self-maintaining. They are sustained by a consensus broadly shared within the polity that their policy aims are worthy of continued pursuit. To be sure, the consensus that sustains them need not be incontestable. Like all public policy, there are often dissenting publics whose task it is to contest and render contestable the majoritarian consensus. But as long as the consensus with respect to the policy aims of the superstatute holds across relevant and influential issue publics, the statute will continue to be a superstatute.

By the same token, superstatutes die when the consensus that sustained them dissolves. This can happen in one of two ways. One possibility is that the views of those who have continually disagreed with the policy aims of the statute prevail in important spheres of influence-whether in legislatures, courts, or elite public opinion. The statute would be regarded as a mistake, and there would be a reversal on the merits. In such a case, Congress would repeal the superstatute or allow it to expire if it contained a sunset provision. The second means of dissolution arises when crucial publics begin to question whether the statute remains necessary on the theory that it has accomplished its public policy aims. This is where we find ourselves with the VRA.

The VRA's status as a superstatute depended upon a consensus with respect to the need to eradicate state-sponsored racial discrimination in voting. The existence of racial discrimination served as a moral justification for the VRA, supported the interbranch cooperative approach that had maintained the VRA, and justified the Court's pragmatic interpretation of the VRA. As long as the racial discrimination consensus remained, the VRA's status as a superstatute endured.

As we argue in this Part, the Court's decision in Shelby County reflects the complete dissolution of the racial discrimination consensus. Shelby County is remarkable not simply because the Court struck down an important provision of the VRA and neutered another, but also because the Court essentially declared an end to the racial discrimination consensus. It was this consensus that had sustained the VRA's superstatute status.

\section{A. THE END OF THE RACIAL DISCRIMINATION CONSENSUS}

Few would disagree with the proposition that the VRA was essential to address the problem of voting discrimination. But there is a profound and growing disagreement on the current need for and relevance of the VRA for the politics of the 21 st century. Chief Justice Roberts warned in Northwest

161. See Shelby Cnty. v. Holder, 133 S. Ct. 261 2, 2629 (2013) ("We cannot... try our hand at updating the statute ourselves."). 
Austin: "Things have changed in the South. Voter turnout and registration rates now approach parity. Blatantly discriminatory evasions of federal decrees are rare. And minority candidates hold office at unprecedented levels." ${ }^{2} 6_{2}$ On this evidence, the Chief Justice implicitly asked, what else is left for the "temporary" section 5 to do? In a sentence that foreshadowed the Court's holding in Shelby County, the Chief complained that "[ $t]$ he statute's coverage formula is based on data that is now more than 35 years old, and there is considerable evidence that it fails to account for current political conditions." $6_{3}$ One can almost hear the Chief Justice explicitly asking the question that was implicit in his Northwest Austin discourse: was there any useful purpose to maintaining an outmoded regulatory regime that had already achieved its public policy aims, especially in light of the purported "federalism costs" imposed by the statute?

Four years later, writing for the majority in Shelby County, the Chief reprised the same refrain. "Nearly 5o years later," he proclaimed authoritatively, "things have changed dramatically." $16_{4}$ In particular, "[b]latantly discriminatory evasions of federal decrees are rare." $6_{5}$ Notwithstanding these changes, "the Act has not eased the restrictions in [section] 5 or narrowed the scope of the coverage formula in [section] 4 (b) along the way." 66

Note the arresting plethora of adjectives that the Chief Justice deployed in the opening paragraph of his opinion in Shelby County to depict the supposedly aberrant nature of the problem and the fact that the Voting Rights Act was out of the mainstream of congressional action. The adjective "extraordinary" makes two noteworthy appearances, and both in the first sentence. ${ }^{167}$ "Drastic," materializes in the second sentence. ${ }^{168}$ "Dramatic" provides flourish to the third sentence. ${ }^{169}$ "Strong" anchors the fourth sentence. ${ }^{170}$ "Exceptional" is borrowed woodenly from the Court's landmark precedent in South Carolina $v$. Katzenbach to support the fifth sentence. ${ }^{171}$ "Unprecedented" closes out the paragraph. ${ }^{12}$

These adjectives encapsulate Chief Justice Roberts's story about the VRA. The Chief Justice tells a story where racism in voting was an extraordinary and

162. Nw. Austin Mun. Util. Dist. No. One v. Holder, 557 U.S. 193, 202 (2009).

163. Id. at 203 .

164. Shelby Cnty., 133 S. Ct. at 2625.

165. Id. (quoting Nw. Austin, 557 U.S. at 202).

166. Id. at 2626 .

167. Id. at 2618 ("The Voting Rights Act of 1965 employed extraordinary measures to address an extraordinary problem.").

168. Id.

169. Id.

17 o. Id.

171. Id.

172. Id. 
unprecedented problem that required extraordinary and strong remedies, and which resulted in drastic and dramatic departures from constitutional principles. At the heart of this remedial scheme stood the coverage formula, which helped Congress target the special provisions of the Act to where they were most needed. The formula was initially based on registration and turnout data from the 1964 election cycle and was last updated in $1972 .^{173}$ And after almost $4^{\circ}$ years, the Chief Justice argued, the Act accomplished what it set out to do.

According to this story, the mission of the VRA has been accomplished in two ways. First, voters of color are registering to vote, voting, and electing their representatives of choice at growing rates. Second, racism is waning. To be sure, the Court noted that "voting discrimination still exists; no one doubts that." ${ }^{774}$ But it concluded that instances of racism were not sufficiently systematic to justify the coverage formula any longer. Or, as the Chief Justice made clear in the second paragraph of his opinion for the majority, " $[t]$ here is no denying, however, that the conditions that originally justified these measures no longer characterize voting in the covered jurisdictions." ${ }^{175}$

Put differently: things have changed, but the VRA has not. Hence, while the coverage formula met the relevant constitutional test in $196_{5}$, it no longer meets the test today. ${ }^{176}$ More generally, the Act's "extraordinary" provisions no longer "continue to satisfy constitutional requirements." 177 And with that, the Court declared an end to the racial discrimination consensus, struck down the coverage formula, neutered the preclearance requirement, and delivered a mortal blow to the crown jewel of the civil rights movement. Northwest Austin and Shelby County are only the latest expression of the dissensus that now envelops the VRA. This is a dissensus that is predictably reflected in the political process, ${ }^{178}$ in prior Supreme Court cases, ${ }^{179}$ and less predictablythough no less fervently-in academic circles. ${ }^{180}$

\footnotetext{
1 73. See Nw. Austin Util. Dist. No. One v. Holder, 557 U.S. 193, 200 (2009).

174. Shelby Cnty., 133 S. Ct. at 2619.

175. Id. at 2618 .

176. Id. at 2631 .

177. Id. at 2619 .

178. See S. REP. No. $109-295$, at 2 (2006) (noting that great strides have been made in race discrimination).

179. See, e.g., Bush v. Vera, 517 U.S. $95^{2}$ (1996) (considering a challenge to a Texas redistricting plan); Miller v. Johnson, 515 U.S. goo (1995) (considering a challenge to a Georgia redistricting plan); United States v. Hays, 515 U.S. 737 (1995) (considering a challenge to a Louisiana redistricting plan); Shaw v. Reno, 509 U.S. 63o (1993) (considering a challenge to a North Carolina redistricting plan).

180. See, e.g., Issacharoff, supra note 12; Overton, supra note 7; Richard $\mathbf{H}$. Pildes, The Future of Voting Rights Policy: From Anti-Discrimination to the Right to Vote, 49 How. L.J. 741 (2006).
} 


\section{B. THREE CONCEPTIONS OF DISSENSUS}

"Things have changed" is the theme of both Northwest Austin181 and Shelby County. ${ }^{82}$ This is due in no small measure to the VRA. As a result, this is where the dissensus in voting rights law and policy is keenly reflected. It is far from clear, in other words, exactly what the "things" are that have changed. This nondescript noun, "things," subsumes-really conceals-a number of important inquiries about voting rights policy as the VRA reaches the midcentury mark. In this Subpart we explore three "things" that have arguably changed since the VRA was enacted: (1) the ubiquity and evolving conception of intentional racial discrimination in voting; (2) the internal coherence of the VRA's geographical targeting approach; and (3) the extent to which what was once a race problem is now a partisanship problem. Taken together, these "things" and the dissensus that envelops them place great stress on the VRA as the proper guardian of voting rights for the questions of the 21 st century.

\section{What Is Racial Discrimination?}

One of the "things that have changed" is our confidence in the prevalence and pervasiveness of intentional discrimination by state actors. The consensus that prevailed over the need to rein in state-sponsored racial animus in voting has given way to a debate-which one commentator describes as "a rather sterile exchange" 189 - over whether we have made sufficient progress on this front to justify the unwinding of the VRA (as a matter of public policy) or the Court's retreat in Shelby County (as a matter of constitutional law).

Moreover, focus on the noun "discrimination," and not on the adjective "racial," and consider what counts as racial discrimination for modern voting rights policy? Is it only state action? Racially polarized voting by the electorate? ${ }^{18_{4}}$ Racist beliefs? ${ }^{185}$ Voting laws that have a disparate racial impact? ${ }^{186}$ Once we have made significant progress on minimizing, though not eliminating first-order racial exclusion, how else are we to understand racial discrimination? Until recently, voting rights doctrine did not need to parse through these niceties. Having witnessed the South turning hoses on

181. Nw. Austin Mun. Util. Dist. No. One v. Holder, 557 U.S. 193, 202 (2009) ("Things have changed in the South.").

182. Shelby Cnty., 133 S. Ct. at 2625 ("Nearly $5^{\circ}$ years later, things have changed dramatically.").

183. Issacharoff, supra note 12 , at 99 .

184. See, e.g., Stephen Ansolabehere et al., Race, Region, and Vote Choice in the 2008 Election: Implications for the Future of the Voting Rights Act, 123 HARV. L. REV, $13^{8} 5$ (2010); Stephen Ansolabehere et al., Regional Differences in Racial Polarization in the 2012 Presidential Election: Implications for the Constitutionality of Section 5 of the Voting Rights Act, 126 HARV. L. REV. F. 205 (2013).

185. See, e.g., Elmendorf \&c Spencer, supra note 7.

186. See, e.g., Ellen Katz et al., Documenting Discrimination in Voting: Judicial Findings Under Section 2 of the Voting Rights Act Since 1982, 39 U. MICH. J.L. REFORM 643 (2006). 
black citizens attempting to exercise their fundamental rights, we understood discrimination, as the Katzenbach Court said, as "an insidious and pervasive evil which had been perpetuated in certain parts of our country through unremitting and ingenious defiance of the Constitution." ${ }^{187}$ But as voting rights lawyers and scholars begin to think of a response to Shelby County, they will need to provide a compelling account of what constitutes racial discrimination in voting in the 21 st century. These types of inquiries are inevitable, and we do not have any consensus or obvious path forward.

\section{Does Geographical Targeting Remain Sensible?}

A less sterile candidate for the "things that have changed" category is section 4 (b)'s justification for targeting specific states and local jurisdictions for regulatory scrutiny, which resulted in the subjection of almost all of the southern states to the preclearance requirement. Recall here the Chief Justice's question to the Solicitor General during the oral arguments in Shelby County: "Is it the government's submission that the citizens in the South are more racist than the citizens of the North?" 188 Maybe. ${ }^{89}$ But this question is a red herring and a tendentious debater's trick. The real question for voting rights law and policy in the 21 st century is not whether the South is more racist than the North; the real question is whether it remains a sensible policy to identify and target areas of the country where voting rights problemsread: minority voting rights problems-are likely to arise. ${ }^{190}$

This was precisely what the VRA did. The Act was aimed at the South, the region of the country that had systematically denied the right to vote to African Americans for decades. This made sense since, pretensions about the neutrality of the coverage formula aside, "it was very clear which jurisdictions were the most egregious offenders." ${ }^{191}$ But this is much less so today. Geography explains or predicts only few of our concerns about voting discrimination.192 Take the current preoccupation with voter photo identification laws. North Carolina, which had 40 counties designated for coverage by section $4(\mathrm{~b})$, has recently passed one of the strictest photo identification requirements in the country. ${ }^{193}$ Pennsylvania, a non-covered

187. South Carolina v. Katzenbach, $3_{3} 3$ U.S. 301,309 (1966).

188. Transcript of Oral Argument at $4^{1-42}$, Shelby Cnty. v. Holder, 133 S. Ct. 2612 (2013) (No. 12-96); see also Transcript of Oral Argument at 48, Nw. Austin Mun. Util. Dist. No. One v. Holder, 557 U.S. 193 (2009) (No. o8-322) (transcribing the Chief Justice's inquiry as to whether "southerners are more likely to discriminate than northerners").

189. See, e.g., Elmendorf \& Spencer, supra note 7, at $1160-62$.

19o. See Pildes, supra note 180 , at $74^{8}-49$.

191. Guy-Uriel E. Charles \& Luis Fuentes-Rohwer, Mapping a PostShelby County Contingency Strategy, 123 YALE L.J. ONLINE 131,140 (2013).

192. See, e.g., id.; Issacharoff, supra note 12 , at 104 ; Pildes, supra note 180 , at $\mathbf{7 4} 4^{\mathbf{8}} \mathbf{5 5}$

193. See generally North Carolina v. League of Women Voters of N.C., 135 S. Ct. 6 (2014) (issuing a stay to block a Fourth Circuit decision finding portions of North Carolina's 2013 voter identification and registration law unconstitutional). 
state, had a similarly strict law until a state trial court judge struck it down. ${ }^{194}$ Virginia also has a photo identification requirement. ${ }^{195}$ Wisconsin would like to have one, but the Supreme Court struck down its law and left in place permanent injunctions issued by lower courts. ${ }^{196}$ Texas, a formerly covered jurisdiction, has a very strict voter photo identification requirement, ${ }^{197}$ but so does Indiana, ${ }^{19^{8}}$ which was a non-covered jurisdiction. Georgia, a formerly covered jurisdiction, has a stringent voter photo identification requirement. ${ }^{199}$ Kansas, never a covered jurisdiction, has one as well. ${ }^{200}$ If photo identification requirements are the new literacy tests, then section $4^{(b)}$ 's coverage formula is certainly underinclusive and illogical, perhaps significantly so.

In Shelby County the Court asks about the indignity to North Carolina of treating it differently from Indiana, or the indignity to Virginia of being treated as a constitutional stepchild compared to Pennsylvania. The Court has been criticized, and rightly so, for caring more about the dignity of states that for a very long time did all they could to keep black voters from voting, than for being concerned for the dignity of the citizens who were the purported beneficiaries of the Reconstruction Amendments. ${ }^{201}$ But let us shift the angle of our critical inquiry slightly, from the states to the citizenry. What is the justification for protecting voters of color when they are in North Carolina but not in Pennsylvania?202 In Virginia but not in Wisconsin? In Georgia but

194. In January 2014, a state trial court judge held that Pennsylvania's voter identification law violated the state's constitution by impermissibly burdening the fundamental right to vote. Applewhite v. Commonwealth, No. 330 M.D. 2012 , 2014 WL 184988, at *18 (Pa. Commw. Ct. Jan. 17, 2014). Governor Tom Corbett has said that the State will not appeal the ruling. Kate Giammarise, Corbett Says He Will Not Appeal Ruling Against Voter $D$ Law, PITTSBuRGH POST-GAZETTE (May 8, 2014, 5:16 PM), http://www.post-gazette.com/news/state/2014/o5/08/Corbett-sayshe-will-not-appeal-ruling-against-voter-ID-law/stories/ $2014{ }^{\circ} 5^{\circ} 80318$.

195. See VA. CODE ANN. $\$ 24 \cdot 2-404$ (A) (3) (Supp. 2014); id. § 24.2-41 1.1 (F).

196. Frank v. Walker, 135 S. Ct. 7 (2014) (granting an application to vacate the Seventh Circuit decision that reversed the district court's permanent injunction of Wisconsin's voter identification law). A less restrictive law went into effect as the Wisconsin's legislature, and conservative Supreme Court, remain committed to passing a photo identification law. See WIS. STAT. \$ 6.79(2) (Supp. 2014); Tony Mauro, Challenge to Wisconsin Voter 10 Law Heads to Supreme Court, LEGAL TIMES (Jan. 8, 2015, 12:09 PM), http://www.nationallawjournal.com/legaltimes/ id $=1202714369835$ / Challenge-to-Wisconsin-Voter-ID-Law-Heads-to-Supreme-Court.

197. TEX. Elec. CODE ANN. § 15.001 (West 2010 \& Supp. 2014). In October 2014, the Supreme Court refused to vacate the stay entered by the Fifth Circuit on appeal of the district court's injunction against the law. Veasey v. Perry, 135 S. Ct. 9 (2014).

198. IND. CODE $\$ 3^{-10-1-7.2 ~(2006) . ~}$

199. GA. CODE ANN. \$ 21-2-417 (2008).

200. KAN. STAT. ANN. $\$ \$ 25^{-1} 122,-2316 c,-2908$ (West 2008).

201. See, e.g., Charles \& Fuentes-Rohwer, supra note 191; Joseph Fishkin, The Dignity of the South, 123 YALE L.J. ONLINE 175 (2013); Reva B. Siegel, Equality Divided, 127 HARV. L. REV. 1 (2013).

202. Professor Issacharoff has advanced a similar point using Georgia v. Ashcroft, 539 U.S. 461 (2003), and Page v. Bartels, 144 F. Supp. 2d 346 (D.N.J. 2001), to illustrate an analogous point. 
not in Kansas? Is this sensible voting rights policy? If dignity is the measuring stick, why are some citizens of color owed the dignity of having their voting rights protected but others less so? (And should this differential treatment bother us more?) Once again, dissensus abounds.

\section{Race v. Partisanship Redux}

But even more significant for voting rights policy is the partisan turn that has characterized the post-civil rights era. ${ }^{203}$ The leading debate in voting rights scholarship presently is whether race or partisanship best explains modern laws regulating political participation. ${ }^{204}$ Partisanship threatens to supplant race as the dominant explanatory variable for voting rights policy. ${ }^{205}$ This debate will direct the shape of the reform agenda into the future. If partisanship best defines the current voting rights space, then what is the likelihood of success for a reform agenda that depends upon a paradigm of racial exclusion? Moreover, how are we to justify judicial supervision of voting rights policy? If partisanship rather than race best explains modern laws regulating political participation, can we transfer our account justifying judicial supervision of racialized politics to the realm of partisanship? If not, can we justify the judicial supervision of partisan political behavior?

Three developments concerning this partisan turn are pertinent to the future of voting rights policy. The first development is the transformation of the South from a one-party region, once dominated by the Democratic Party, to a region in which the Republican Party is now the majority party. As one political scientist and expert on southern politics noted, " $[t]$ he emergence of the Republican party as a realistic alternative to the Democrats is the most dramatic story in southern politics during the late twentieth and early twentyfirst centuries." ${ }_{206}$

This development is important for at least three reasons. First, the Republican Party can now contend at the national level.207 Second, and most

See Samuel Issacharoff, Is Section 5 of the Voting Rights Act a Victim of Its Own Success?, $10_{4}$ COLuM. L. REV. $1710,1728-29$ (2004).

203. See Richard L. Hasen, Race or Party?: How Courts Should Think About Republican Efforts to Make It Harder to Vote in North Carolina and Elsewhere, 127 HARV. L. REV. F. 58 (2014); Overton, supra note 7 .

204. See, e.g., Hasen, supra note 203; Issacharoff, supra note 12; Pildes, supra note 180.

205. See Issacharoff, supra note 12, at 100 (arguing that the "current voting controversies, unlike the concerns of racial exclusion under Jim Crow, are likely motivated by partisan zeal and emerge in contested partisan environments").

206. Merle Black, The Transformation of the Southern Democratic Party, 66 J. POL. 1001, 1001 (2004); see also DAvid LUBLIN, THE REPUBLICAN SOUTH: DEMOCRATIZATION AND PARTISAN CHANGE (2004) (documenting and explaining the slow rise of the Republican Party in the South).

207. EARL BLACK \& MERLE BLACK, THE RISE OF SOUTHERN REPUBLICANS 2 (2002) ("Republicans from the South have transformed American politics. The collapse of the solid Democratic South and the emergence of southern Republicanism, first in presidential politics and later in elections for Congress, have established a new reality for America: two permanently competitive national political parties."). 
obviously, there is political competition in the South whereas before there was none. Third and less obviously, because of the increased competition between the two dominant parties, the parties have an incentive to engage in political rent-seeking by using voting regulation to gain a competitive advantage.

The second development is the complete transformation of the Democratic Party from a party that was in part indifferent to voting equalitythe Democratic Party in the North-and was in part racist-the Democratic Party in the South-to a Democratic Party now fully identified as the party that represents the interest of voters of color. Whereas voters of color, in particular black voters, were once excluded-and often violently so-from participation in democratic politics in the one-party South, they are now a key constituency of the Democratic Party in the South. Moreover, the Democratic Party in the South is increasingly the party of not just African-American voters but of Latinos, Asian Americans, and other citizens of color.

The third development is the growing partisan and ideological polarization that has been a function of American political reality for the last $4^{\text {o years. }}{ }^{208}$ Though there is a debate within political science literature on whether the mass public is in fact polarized, few scholars doubt that elites are polarized and that the parties are as polarized as they have been in generations. Notwithstanding the dispute in political science literature on mass polarization, researchers have found strong evidence of partisan sorting, the process by which voters bring their ideology, liberal or conservative, in line with their partisan identity. Thus, to quote from an apt title of a recent book, "liberals became Democrats and conservatives became Republicans." 209

This last development is particularly important because it shows that voting rights have now been recast as a partisan issue. According to political scientists Ted Carmines and James Stimson, citizens learn the differences between the political parties on particular issues after elites take positions in partisan terms. ${ }^{210}$ Elite positioning communicates to the citizens the parties' position on the issues. To the extent that the issue is one that is salient to the citizens, citizens will bring into line their issue position with their partisan

208. Andrew Garner \& Harvey Palmer, Polarization and Issue Consistency over Time, 33 POL. BEHAV. 225, 226 (2011) ("There is broad scholarly consensus that the political environment has become more ideologically divided over the past several decades.").

209. MatThew Levendusky, The Partisan Sort: How Liberals Became Democrats and CONSERVATIVES BECAME REPUBLICANS (2009).

2 10. See generally EDWARD G. CARMINES \& JAMES A. STIMSON, ISSUE EVOLUTION: RACE AND THE TRANSFORMATION OF AMERICAN POLITICS (1989); Edward G. Carmines \& James A. Stimson, Issue Evolution, Population Replacement, and Normal Partisan Change, 75 AM. POL. SCI. REV. 107 (1981); Edward G. Carmines \& James A. Stimson, On the Structure and Sequence of Issue Evolution, 8o AM. POL. SCI. REV. go1 ( 1986 ) [hereinafter Carmines \& Stimson, Structure and Sequence]; Edward G. Carmines \& James A. Stimson, The Two Faces of Issue Voting, 74 AM. POL. SCI. REV. 78 (1980). 
identity. Mass polarization will thus reflect elite polarization. ${ }^{211}$ This framework has been confirmed by recent work in the field. ${ }^{212}$

In this new age of party polarization, many issues are filtered through a partisan lens. ${ }^{213}$ The Affordable Care Act ("ACA"), modeled after a health exchange program supported and promulgated by Republican thenGovernor of Massachusetts and later Republican nominee for president, Mitt Romney, is vigorously opposed by Republicans and strongly supported by Democrats, in significant part because the policy is the signature legislative achievement of the Democratic President, Barack Obama. ${ }^{214}$ President Obama's frequent reminder that the ACA was a Republican idea has not made the statute any more popular with Republican voters. When George W. Bush, the Republican former president, was in the White House, the vast majority of Democrats opposed the practice of data-mining by the National Security Agency. Now that Mr. Obama is in the White House, the vast majority of Democrats now support the practice. A significant proportion of black voters who were thought to be staunchly opposed to same-sex marriage changed their issue position after President Obama announced his public support for the practice. These are examples of a general phenomenon characteristic of the politics of the early 21 st century: taking their cues from political elites, voters modify their positions on the issue to bring their issue position in line with their political identity. ${ }^{215}$

The implications of this hyper-partisanship for voting rights policy is to transform a cause clothed in the moral righteousness of the civil rights movement to a cause defined only by partisan politics. At the dawn of the VRA, the Democratic Party dominated the South. The northern wing of the party, at the insistence of then-President Lyndon Johnson, with critical Republican support, overcame the filibuster from Southern Democrats and enacted the VRA. Voting rights law and policy were a moral crusade. It was

211. As Carmines and Stimson argue, "visible changes in elite behavior serve to redefine party images, to affect emotional response to the parties, and ultimately to realign the constellation of voter issue attitudes and party identifications to reflect earlier changes among the elite." Carmines \& Stimson, Structure and Sequence, supra note 210 , at 904.

212. Joseph Bafumi \& Robert Y. Shapiro, A New Partisan Voter, 71 J. POL. 1, $21-22$ (2009); see also Matthew S. Levendusky, Clearer Cues, More Consistent Voters: A Benefit of Elite Polarization, $3^{2}$ POL. BEHAV. 111, 121-24 (2010) (discussing the results of an experimental test of the relationship between elite polarization and mass polarization).

213. This is to say, not all issues are similarly prone to such filtering. Saliency is crucial. See Kara Lindaman \& Donald P. Haider-Markel, Issue Evolution, Political Parties, and the Culture Wars, 55 POL. RES. Q. 91, 94-95 (2002).

214. See Health Tracking Poll: Exploring the Public's Views on the Affordable Care Act (ACA), HENRY J. KAISER FAM. FOUND., http://kff.org/interactive/health-tracking-poll-exploring-the-publicsviews-on-the-affordable-care-act-aca/ (last visited Mar. 4, 2015).

215. This phenomenon is not fully elastic. On some issues voters might be willing to leave their political party and unwilling to switch their positions. 
not a partisan issue but, in fact, a bipartisan one. ${ }^{216}$ Indeed, one can describe the VRA as the outcome of an intra-party fight; the Democratic Party was split between its northern and southern sections. The northern section won, as evidenced by the Civil Rights Act of 1964 and the Voting Rights Act of 1965 . Section 5, the most powerful tool in the VRA toolkit, was sanctioned by a Democratic president and it "served to ratchet up black political power at the expense of the encrusted white establishment of the Democratic Party." ${ }_{217}$

Today, at the twilight of the Voting Rights Act, voting rights policy itself, not just the VRA, is not understood as a moral issue, but as a partisan one. Democrats favor the VRA; Republicans do not. Democrats favor limits on campaign financing; Republicans do not. Republicans favor strict voter identification requirements and believe that they are legitimately aimed toward assuring the integrity of elections; Democrats view voter identification requirements as attempts to suppress the vote of legitimate voters. As Professor Samuel Issacharoff noted recently: "No state under Democratic control passed significant voter identification laws or sought to restrict early voting or voter access in the run-up to the 2012 presidential elections." ${ }_{218}$ The political parties are ideologically divided on the role of the state in facilitating political participation.

If partisanship remains the dominant explanatory variable for the enactment of state laws that regulate political participation, it is not sensible for voting rights activists to continue to insist on understanding these laws in racial terms. ${ }^{219}$ This is so for at least three reasons.

First, as a matter of public policy, the reform agenda is less likely to be successful if it has misidentified the problem. If the problem is more about partisanship and less about racism, a race-based solution is imprudent and bound to fail as a matter of politics. Second, as a matter of constitutional law, the Court has curtailed Congress' power to implement a race-based solution. ${ }^{220}$ Third, and in our view most importantly, the project of eradicating the vestiges of racism in voting (the voting rights project) and in society at

216. For example, in the mid-196os, "whenever he spoke in the South, [Richard Nixon] iterated his support of the Civil Rights Act of 1964 and the Voting Rights Act of 1965 ." 2 STEPHEN E. AMbrose, NixON: THE TrIUMPH OF A POLITICIAN 1962-1972, at 89 (1989). Similarly, leading Republicans supported both Acts in Congress. See, e.g., GARY MAY, BEndinc TOWARD Justice: ThE Voting Rights ACT AND THE TRANSFORMation OF AMERICAN DEMOCRACY 149-67 (2013) (recounting the legislative battle to pass the VRA); Gary May, Over 48 Years, GOP Strays Far from Voting Rights, CNN (Aug. 7, 2013, 3:35 PM), http://www.cnn.com/2013/o8/o7/opinion/mayvoting-rights-act/.

217. Issacharoff, supra note 202 , at 1713 .

218. Issacharoff, supra note 12 , at 103; see also Pildes, supra note 180 , at 761 (discussing the partisan element present in the modern voting rights conversation).

219. We recognize, of course, that race and partisanship are related and have been so historically. See, e.g., Hasen, supra note 203; Overton, supra note 7 . But of course, the political place of African-Americans today and other people of color is obviously different than it was in at the end of the $19^{\text {th }}$ century and the beginning of the 20 th century.

220. This point is examined by Issacharoff, supra note 12, at $9^{6-97}$. 
large (the civil rights project) remains an important and necessary endeavor. Relatedly and just as significantly, the importance of calling out racism is an important moral stick and a priceless commodity, but it has a diminishing margin of return. In the aftermath of an opinion in which the Supreme Court has essentially declared that the era of big racism is over, we should only fight about race when we are sure that the fight is in fact about race or when the payoff is only possible if the fight is about race. More concretely: the pursuit of a race-based remedy for voting rights issues might jeopardize the remaining provisions of the VRA and the rest of the civil rights agenda.

\section{FORGING A NEW CONSENSUS: THREE MODELS}

Given the cloud of dissensus gathered over the policy aims of the VRA, the 2006 renewal process presented an opportunity manqué. Generally, periodic expirations of a statute by sunset and renewal provisions achieve at least three goals. First, they provide an opportunity for taking stock. This is a chance for the political process to determine how well the statutory scheme has worked and to assess how much progress the statute has made in accomplishing its goals. Second, this is also an occasion for celebrating successes. Third, it provides an opportune moment for retooling or updating the statute to better-fit changed circumstances. Or to put it differently, this is an opportunity to build a new and perhaps narrower consensus. Theoretically, as progress is made, Congress ought to discard older and less useful measures while fashioning new ones to address present and future concerns.

This is what one would have expected Congress to do with the occasion provided in 2006, but this is not what Congress did. The 2006 Reauthorization Act accomplished two substantive goals. First, the Act overruled Reno v. Bossier Parish ("Bossier II"). In Bossier II, the Supreme Court held that the Attorney General must preclear a redistricting plan that may have been motivated by discriminatory animus if it was not enacted with the intent to make voters of color worse off. ${ }^{221}$ Second, Congress overruled Georgia v. Ashcroft. In Ashcroft, the Supreme Court held that the legislature may trade safe majority-minority districts-districts in which voters of color are guaranteed to elect a candidate of their choice-for coalition or influence districts.222 Note, unfortunately, that both substantive goals of the Reauthorization Act are backward-looking and only sought to restore the status quo ante.

221. Reno v. Bossier Parish Sch. Bd., 528 U.S. $320,34^{1}$ (2000).

222. Georgia v. Ashcroft, 539 U.S. $461,4^{8} 3$ (2003). A "coalition district" is a district in which voters of color are numerous enough to be able to coalesce with like-minded voters in selecting their candidate of choice. In contrast, "influence districts" are districts where voters of color are not quite as numerous as in coalition districts, yet their numbers are large enough to allow them to influence the selection of the district's candidate. See Richard H. Pildes, Is Voting-Rights Law Now at War with Itself? Social Science and Voting Rights in the 2000 , 80 N.C. L. REv. ${ }^{1} \mathbf{5}^{7}$, 1539-40 (2002). 
We are particularly puzzled by the congressional reversal of Ashcroft, which was purportedly the Reauthorization Act's signature accomplishment. In overturning this decision, Congress sought to return to the status quo ante and the Court's opinion in Beer $v$. United States. ${ }^{23}$ At issue in Ashcroft was whether the state, a covered jurisdiction, violated Beer's non-retrogression standard when it reduced the percentage of black voters in three state senate districts from $60.58 \%, 55.43 \%$, and $62.45 \%$ to $50.31 \%, 50.66 \%$, and $50.80 \%$ respectively.224 The lower court concluded that the reduction was retrogressive because it reduced the opportunity of African-American voters in those districts to elect candidates of their choice. The Supreme Court disagreed. The Court noted that a reduction in the opportunity to elect is neither the sole nor determinative factor in determining retrogression. Rather, retrogression is determined by the totality of all applicable circumstances, "such as the ability of minority voters to elect their candidate of choice, the extent of the minority group's opportunity to participate in the political process, and the feasibility of creating a nonretrogressive plan."225

In the Reauthorization Act, it is clear that Congress sought to return the section 5 inquiry to Beer's mechanical and restrictive retrogression standard, though the language of the law is far from clear. According to the Reauthorization Act, covered jurisdictions cannot "diminish[] the ability ... [of voters of color] to elect their preferred candidate of choice." ${ }_{226}$ The problem is precisely how one determines who the candidate of choice is and what it means to diminish the ability to elect that mysterious character. That Congress did not provide any guidance on either part of the inquiry exacerbated the problem. ${ }^{227}$

Determining the "preferred candidate of choice" ("PCOC") involves a series of difficult and fundamental policy questions that vary depending upon political context. Is the PCOC the candidate who emerges after the creation of a "naturally arising" majority-minority district where one can be created?228 Suppose that there is no "naturally arising" majority-minority district, but the state can manufacture one-is the representative that is the product of that district the PCOC? Suppose that the state cannot create a majority-minority district without violating the Fourteenth Amendment-is the state obligated

223. Beer v. United States, 425 U.S. 130, 141 (1976) (holding a reapportionment plan valid where it had the effect of improving the position of minority voters).

224. Ashcroft, 539 U.S. at $47^{2-73}$.

225. Id. at 479 .

226. Fannie Lou Hamer, Rosa Parks, and Coretta Scott King Voting Rights Act Reauthorization and Amendments Act of $2006 \S 5,42$ U.S.C. $\$ 1973^{\mathrm{C}}(2012)$.

227. Nathaniel Persily, The Promise and Pitfalls of the New Voting Rights Act, 117 YaLE L.J. 174, $2{ }_{16-17}(2007$ ) (noting that Congress failed to provide guidance on the meaning of "candidate of choice").

228. See generally League of United Latin Am. Citizens v. Perry, 548 U.S. 399 (2006) (applying a candidate of choice framework). 
to create coalition districts and would the PCOC be the product of that coalition? What happens when white voters coalesce with enough voters of color to produce a moderate black candidate such as Denise Majette ${ }^{229}$ over the preference of the majority of black voters who would have wanted a more radical, Cynthia McKinney-type ${ }^{23^{\circ}}$ of a candidate? Which one is the PCOC?

PCOC is a function of the array of legislative candidate options from which voters of color must choose. However, those choices are themselves in large part a function of other prior contextual variables, in particular the composition of the voting district. ${ }^{231}$ Political choices do not exist in a vacuum or in the ideal. PCOC is an endogenous variable. More pointedly, PCOC is an endogenous contextual variable that can best be evaluated by examining the totality of circumstances on the ground.232

Ultimately, these types of inquiries force the inquirer to arrive at a normative determination with respect to the fundamental policy aims of the VRA in rapidly changing political environments. In order to determine whether, for example, dismantling a majority-minority district in favor of three influence districts is an unlawful diminishment of the opportunity of voters of color to elect their candidate of choice, we must have some shared understanding about the purpose of the VRA. The absence of such broad agreement and the disintegration of the old understanding is precisely what is wreaking havoc with voting rights policy.

Consider three different ways of making sense of the policy aims of the VRA. First, one can view the VRA as a statute that is directed strictly toward eliminating racial discrimination in the political process. This is the discrimination model. Under this model, a state practice would not violate the Act unless the practice was motivated by racial animus. The discrimination model is most effective where racial discrimination is rampant and poses significant concerns in the political process.

Second, one can understand the VRA as a statute that seeks to confer political autonomy to voters of color as a group unmoored from racial discrimination. Under this model, which we label the autonomy model, the participatory right voters of color are not dependent upon the existence of racial discrimination in voting. The claim is consequential and not expressive. It is not enough that voters of color are able to register and have their votes counted. Voters of color must also be able to wield consequential political power.

2 29. Majett, Denise L., U.S. HOUSE REPRESENTATTVES, http://history.house.gov/People/ Detail/18762 (last visited Mar. 4, 2015).

23o. McKinney, Cynthia Ann, U.S. HOUSE REPRESENTATIVES, http://history.house.gov/ People/Detail/ 17982 (last visited Mar. 4, 2015).

231. See generally David T. Canon et al., The Supply Side of Congressional Redistricting: Race and Strategic Politicians, $197^{2-1992,} 5^{8}$ J. POL. 846 (1996).

232. Recall here Judge Robinson's district court opinion in Beer. Beer v. United States, 374 F. Supp. $3^{63}, 3^{84}$ (D.D.C. 1974), vacated, $4^{25}$ U.S. 130 (1976). 
Third, one can think of voting rights policy in universalist terms. Under this universal voting rights model, the VRA would be a statute that protects a constellation of rights collectively understood as voting rights. On this view, the VRA would not be about race or people of color. It would be a statute that guarantees a positive right to political participation to all voters in all jurisdictions. This VRA would be potentially applicable to any state statute that burdens the right of any individual or identifiable group of people to participate in the political process.

Each model is currently represented in one form or another in voting rights policy. One can easily see the racial discrimination model at work in South Carolina v. Katzenbach and Allen, two key pillars of that model. The racial discrimination model is also the best framework for understanding the current coverage formula under section 4 and the preclearance requirement under section 5 . The coverage formula presumes that we have identified the relevant bad actors and the preclearance requirement is a concession to the fact that we are unable to recognize their bad acts without closer scrutiny.

One can also find the autonomy model at work in voting rights policy and jurisprudence. This model may be the best framework for making sense of section 2 of the VRA as amended in 1982. Note that the Gingles factors, which determine when majority-minority districts can be drawn, do not include a racial discrimination inquiry. ${ }^{233}$ As long as the minority group is sufficiently large and cohesive, and has different political preferences than the white majority, majority-minority districts can be an appropriate remedy. In the absence of a discrimination inquiry, the racial discrimination model cannot explain why we recognize the concept of racial vote dilution under section 2 of the VRA. The concept of vote dilution, rend from a racial discrimination inquiry, is perfectly sensible where voters of color are normatively entitled to wield consequential political power on political group autonomy grounds.

Some tendrils of the universal model extend to voting rights law and policy. In some respects, the incorporation of language minorities in the VRA and the inclusion within the coverage formula of jurisdictions that require election materials to be produced in English-only is a small gesture in the direction of the universal model. The promulgation of the Help America Vote Act is clearly an attempt to move voting rights law and policy in a universalist

233. Thornburg v. Gingles, 478 U.S. $30,5^{\circ-51}$ (1986) (interpreting the 1982 Amendments to section 2 of the VRA and establishing what became known as the Gingles factors: ( 1 ) whether "the minority group . . . is sufficiently large and geographically compact to constitute a majority in a single-member district"; (2) whether "the minority group . . . is politically cohesive"; and (3) whether "the white majority votes sufficiently as a bloc to enable it-in the absence of special circumstances ... usually to defeat the minority's preferred candidate"). 
direction. ${ }^{294}$ Moreover, the political and judicial debate over the lawfulness of voter identification requirements and felony disenfranchisement provisions is most fruitful when framed not in racial discrimination terms but in universalist political participation terms. After all, what is the justification for being more disturbed when an African-American man is denied the right to vote in a state because of prior criminal conviction than when a white woman is denied the same right for the same reason?

The need to grapple with these models could not be more important. This is because, without question, we are in "a transitional moment in American democracy."295 Voting rights law and policy oscillates among these three models as we witness the decline of the racial discrimination model. The type of overt racism that gave rise to the VRA in the last century has virtually disappeared, ${ }^{296}$ there is evidence that racial bloc voting has decreased,,977 and the public policy preferences of voters of color are perceptibly, though slowly, diffuse. ${ }^{89^{8}}$ Against this backdrop, the discrimination model is difficult to sustain. But the extent of racial progress is also difficult to ascertain. Simply, we live in a period of uncertainty.

With voting rights policy at a crossroads, this is precisely where Congressional leadership is crucial..239 Congress is the more competent decision maker because of its ability to engage in systematic empirical or policy analysis. The costs of decision making in this period of uncertainty increase when courts, which are ill-equipped to engage in the systematic overview of the empirical issues raised by the VRA, assume primary policy making responsibilities. In order to see this more clearly, consider once more the dispute over Georgia v. Ashoroft and Beer $v$. United States.

From the perspective of the autonomy model, Ashcroft is as right a voting rights case as we have seen from the Supreme Court in a long time. This is

\footnotetext{
234. Help America Vote Act of 2002, 42 U.S.C. $\$ \$ 15301-15545$ (2012) (providing financial support and assistance for general-election administration purposes, as well as establishing minimum requirements for election administration).

235. Pamela S. Karlan, The Reconstruction of Voting Rights, in RACE, REFORM, AND REGULATION OF THE Electoral Process: RecurRING PUZZLES In AMERICAN DEMOCRACY 34, 35 (Guy-Uriel E. Charles et al. eds., 2011 ).

236. See Richard L. Hasen, Congressional Power to Renew the Preclearance Provisions of the Voting Rights Act After Tennessee v. Lane, 66 OHIO ST. L.J. 177, 188 (2005).

237. See, e.g., Zoltan L. Hajnal, White Residents, Black Incumbents, and a Declining Racial Divide, 95 AM. POL. SCI. REV. 603, 613 (2001).

238. For a review of the literature, see generally Maria Krysan, Prejudice, Politics, and Public Opinion: Understanding the Sources of Racial Policy Attitudes, 26 ANN. REV. SoC. 135 (200o).

239. In a very interesting and important article, Professor Ellen Katz has argued that neither Congress nor the Court is good at figuring out how to update statutes that prescribe remedies for racial discrimination. See generally Ellen D. Katz, Engineering the Endgame, 1 og MICH. L. REV. 349 (2010). She argues that Congress is overly slow to respond to changing circumstances while the Court is too quick to change course and that neither approach is satisfactory. $I d$. at 351 .
} 
because this decision fatally undermined the Court's decision in Beer. ${ }^{24^{\circ}}$ Beer imposed both a floor and a ceiling on the electoral prospects of voters of color and did so in a way that is completely contrary to the aims of the VRA. Under Beer, as long as a jurisdiction did not make voters of color worse off, the jurisdiction did not violate section 5 . That standard might be fine depending upon the baseline, but under Beer the baseline could be 1965 . Thus, section 5 under Beer did not require progress or improvement; it simply did not permit retrogression-as if one could retrogress from zero.

In contrast to Beer, the underlying premise of Ashcroft is that section 5 must be sufficiently flexible to allow for progress. Where voters of color are inefficiently grouped-as, say, in a $60 \%$ black voting-age population districtthe state may reduce the number of voters of color in that district and spread them to other districts as to allow them to aggregate with like-minded others or to have a greater impact on electoral outcomes. Of course, whether that strategy is worth pursuing depends upon contextual factors for which risk is a function of the denouement of real world circumstances. This is not quite "a sea of imponderables." ${ }^{241}$ Some of the factors, such as the extent of racial bloc voting and white crossover voting, are sufficiently ponderable. But others are, admittedly, less so.

In periods of uncertainty one needs "a solution that accommodates imponderables and does not demand precision where the nature of the subject can yield only approximations." ${ }^{42}$ The Court's decision in Ashcroft was such an attempt to implement a contextual and nuanced approach that deemphasized the focus on PCOC and introduced other variables into the equation. ${ }^{243}$

The difficult issue presented in Ashcroft (and Beer) is this: how should the Court assess whether state actors are moving voters of color around in order to enhance or to diminish their electoral prospects? ${ }^{244}$ All of the justices in

240. It is of course ironic that Congress and the civil rights community clamored to resurrect an opinion-Beer-that had long been viewed as inimical to voting rights. Granted, in assessing the outcome in Georgia $v$. Ashcroft, Congress and the civil rights community were possibly distracted by the fact that the right approach in that case came from the Court's conservatives.

241. Vieth v. Jubelirer, 541 U.S. 267, 290 (2004).

242. Pub. Serv. Comm'n of Utah v. United States, $35^{6}$ U.S. $4^{21}, 4_{3}^{6}$ (1958) (Frankfurter, J., dissenting).

243. Georgia v. Ashcroft, 539 U.S. 461, 479 (2003) (“[A]ny assessment of the retrogression of a minority group's effective exercise of the electoral franchise depends on an examination of all the relevant circumstances, such as the ability of minority voters to elect their candidate of choice, the extent of the minority group's opportunity to participate in the political process, and the feasibility of creating a nonretrogressive plan.").

244. Justice Marshall raised similar questions in his Beer dissent:

Is an increase in the size of an existing majority ameliorative or retrogressive? When the size of the majority increases in one district, Negro voting strength necessarily declines elsewhere. Is that decline retrogressive? Assuming that the shift from a $50.2 \%$ to a $52.6 \%$ majority in District $\mathrm{B}$ in this case is ameliorative, and is not 
Ashcroft agreed that some moving around is warranted, in light of changed circumstances-and particularly the appreciable decrease in racial bloc voting in covered jurisdictions. Depending upon the factual circumstances, for example, a $60 \%$ black district could be vote dilution by packing. What divided the Court was determining how to assess the appropriate level of risk and who should bear the risk of an incorrect assessment.

If one believes that state actors cannot be trusted because they will take every opportunity to discriminate, then Beer is the preferred default option and the discrimination model is the preferred model. The civil rights community thought the Court's decision in Ashcroft would undermine the VRA by permitting state actors to dismantle majority-minority districts and replace them with coalition or-even worse, from the perspective of civil rights groups-influence districts, in which voters of color could not control but could only influence the outcome of an election.

Here, tremendous trade-offs are needed. As a consequence, Congress is the best institution for providing the facts necessary to accurately assess the risks. How much has racial bloc voting declined in covered jurisdictions? To what extent are state actors intent on discriminating against voters of color in the political process? Are political incumbents trustworthy guardians of the political interests of voters of color? Should states have the option to implement alternative voting structures and escape review of reapportionment plans? How should we balance competing claims to political autonomy among the different racial groups?245 These are the types of questions that Congress is better positioned to answer, rather than courts under the inherent limitations of the adjudicatory process. ${ }^{2}{ }^{6}$

But Congress could not overcome the political constraints that would enable it to take on these hard questions and modernize the Act. ${ }^{247}$ It could only do the next best thing: set these hard questions aside for another day. Political avoidance perfectly explains Congress's behavior when it was faced

outweighed by the simultaneous decrease in Negro voting strength in Districts A and $\mathrm{C}$, when would an increase become retrogressive?

Beer v. United States, 425 U.S. 130, 153-54 n.1 2 (1976) (Marshall, J., dissenting).

245. It is clear that voting rights cases are no longer between black and white interests, or Latino, but now include claims by Asian-Americans and the distinctive problems faced by Native Americans. See generally Johnson v. De Grandy, $5_{12}$ U.S. 997 (1994) (confronting a claim of Hispanic vote dilution); Wilson v. Eu, 823 P.2d 545 (Cal. 1992) (in bank) (considering a claim of Asian vote dilution).

246. This is precisely the reason that the Court in Georgia v. Ashcroft used Rep. John Lewis as a proxy for determining the best interest of voters of color in Georgia. The Court itself was unsure, but found that if the civil rights icon, whose testimony the Court said "is not so easily dismissed," gave his seal of approval, that was good enough for the conservative justices. Ashcroft, 539 U.S. at 489 .

247. Persily, supra note 227, at 191-92. 
with the difficult choice of revamping the VRA for a different world..$^{24^{8}}$ Though there was deep disagreement in Congress among both supporters and opponents of the Act regarding the continued utility of section 5 and the changes that needed to be made to the VRA to modernize its provision, Congress felt politically compelled to pass the Reauthorization Act, which essentially preserved the status quo.. ${ }^{49}$ Notwithstanding the fact that the political realities have changed dramatically since the Act first passed ${ }^{25}$ and the same statutory scheme has now been in place for over $4^{0}$ years,,$^{25^{1}}$ Congress proved unable to modify the preclearance process in any way or update section 2 to address current realities.

Renewal of the status quo was the only point of consensus; it was the least common denominator of agreement among the different factions. The civil rights community strongly favored renewal. The Democrats had to favor renewal because their relevant constituencies did too. The Republican leadership in both houses favored renewal as well because the Republican President committed early to renewal. Politically, no one had an incentive against renewal.

Further, given that the consensus existed solely over the status quo, the political benefits derived from the symbolism of preserving the status quoor ostensibly restoring the status quo ante by reversing Bossier II and Ashcrofoutweighed the political costs of asking the hard questions regarding the meaning and the future of the Act. Rethinking the direction of the VRA would have destabilized the fragile coalition that came together in favor of renewal. It would have required Congress to go back to the drawing board and confront fundamental questions such as whether this current structural model of apportioning political power is necessary. Because the existing consensus on the policy aims of the VRA had frayed, but there was nothing in place to replace it, destabilization was a likely outcome. One politically perilous possibility of such rethinking would have been the sunset of section 5. However, neither Republicans nor Democrats were interested in being the entities that killed this superstatute, "a sacred symbol of American democracy." 252

Consequently, Congress ducked all of the difficult policy questions to avoid making tough decisions that would be politically costly and potentially

248. Richard H. Pildes, Political Avoidance, Constitutional Theory and the VRA, 117 YALE L.J. POCKET PART 148, 148 (2007) ("Constitutional theory and design have been dominated by the specter of legislative and executive institutions voraciously seeking to expand their powers. But in modern political practice, the flight from political responsibility-the problem of political abdication-is at least as serious a threat.").

249. Persily, supra note 227, at 191-92; James Thomas Tucker, The Politics of Persuasion: Passage of the Voting Rights Act Reauthorization Act of 2006, 33 J. LEGIS. 205, 267 (2007).

250. See Issacharoff, supra note 202, at 1712.

251. Or 25 years, if one counts from the time of the 1982 amendments.

252. Pildes, supra note 248 , at $15^{2}$. 
destabilizing. By providing a 25-year extension of section 5 , Congress would not be forced to revisit this statutory scheme until 2031. Everyone, particularly the civil rights community, declared victory and went home.

Congress's gamble was that the courts would resolve the difficult questions. This was not an altogether irresponsible gambit. Under the cooperative framework dictated by the partnership model, there was a sufficiently strong possibility that the Court would continue to step in and make the tough calls that Congress could not make for political reasons. In fact, this is the historical evolution of the Act in a nutshell. The question that the Court faced and continues to face was whether it ought to cooperate with Congress's abdication of political responsibility. Ordinarily, one might say that the courts should do what they have always done with respect to the VRA: make the policy decisions as best as they can. But these are not ordinary circumstances.

The fundamental policy judgments that courts are having to make about the future of the VRA, and the choice among different models of the VRA are more difficult than they have ever been. Courts do not have the institutional competence to make these difficult policy judgments. Increasingly, judicial decisionmaking with respect to the VRA is less about effectuating a democratic consensus with respect to the policy aims of the VRA-namely, to rid the electoral process of racial discrimination-and more about choosing between competing normative models of the VRA's purpose. The Chief Justice's complaint that the Act fails to account for current political realities is a fair indictment.

Moreover, superstatutory interpretation, which depends upon a partnership among the branches, functions best where each branch is pulling its own weight and contributing to the resolution of the public policy problem that is the aim of the statute. Congress is proving itself unable to make any more significant contributions, and the Court is no longer willing to decide the next phase of voting rights policy. The executive branch is, for now, the last actor standing. The era of cooperation is over.

\section{CONCLUSION}

Voting rights policy and the VRA stand at a crossroads. Long considered the most successful civil rights statute in American history, the regulatory model that sustained the Act for decades is no longer tenable today. Think about the fact that the VRA was once untouchable. It has been described as "one of the crown jewels of the civil rights movement." ${ }^{253}$ In the midst of its federalism revolution the Court signaled the VRA as essentially model legislation. We have come a long way since those halcyon days. We may never see them again. The superstatute that we knew as the VRA is now a shell of its old self.

${ }^{253}$ Crum, supra note 13 , at 1994 . 
In this Article we sought to provide an explanation for the fall of this superstatute. Fundamentally, the consensus about racial discrimination that supported the VRA has dissolved. The racial discrimination consensus suffered a mortal blow from Shelby County. Going forward, two competing models are available. First is the political autonomy model, which demands that voters of color wield consequential political power simply because they are citizens of the polity. Second is the universal voting rights model, which understands the VRA as protecting a constellation of rights apart from race or color.

To save the VRA, those interested in voting rights policy will need to build support for a model other than the racial discrimination model. But it might be that we can no longer develop the political consensus for moving voting rights policy forward-in which case, we will continue to muddle through. We must be sober-eyed about the task forward; the time for sentimentalism is over. Dissolution also presents an opportunity for rebirth. 


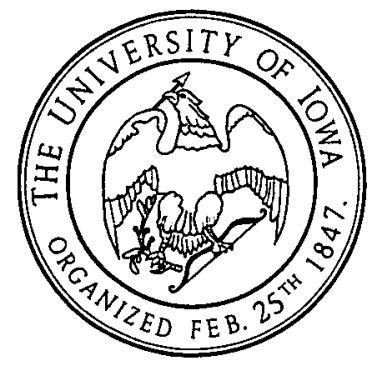

